\title{
Comfort and Connectivity: The Museum as a Healer
}

\author{
Anne Elizabeth Melton
}

\author{
A thesis \\ submitted in partial fulfillment of the \\ requirements for the degree of \\ Master of Arts \\ University of Washington \\ 2012
}

Committee:

Wilson O’Donnell

Donna Linz

Program Authorized to Offer Degree:

Museology 


\begin{abstract}
Comfort and Connectivity: The Museum as a Healer

Anne Elizabeth Melton

Chair of the Supervisory Committee: Wilson O’Donnell

Museology Graduate Program
\end{abstract}

This thesis will seek to address why and how museums can be effective places to help resolve grief and transcend suffering. The objective is to identify practical ways in which museum staff can respond to tragedy which may help inform museum practice.

Through four case studies that highlight museum institutional responses to tragedy, this paper will examine those ways in which museums have responded in the past and how those actions could have contributed to healing. The four case studies examined are:

1. The Oklahoma Museums Association's "A Day for Children" event following the bombing of the Alfred P. Murrah Federal Building

2. The Experience Music Project Museum's hosting of a tribute, memorial service, and encouraging audience expression following the death of musician Michael Jackson

3. The Field Museum's panel discussions, performances and use of a permanent exhibit to interpret and understand the terrorist attacks of September 11, 2001

4. The Oakland Museum of California's annual Days of the Dead celebration as a tribute to slain journalist, Chauncey Bailey

By analyzing the case studies in the context of the resolution of grief and promotion of healing, a framework can begin to be established for museum staff facing a community in crisis. 
The results indicate that museums can be effective in helping their communities and audiences resolve grief and transcend suffering by utilizing their unique individual resources. This can be accomplished by acting as a gathering place where people can be in the presence of others, a necessary component of healing, providing social support and an environment that supports grieving, and/or executing programming, exhibits, or events that respond to a variety of community needs which help that community resolve its grief and regain equilibrium to function fully once again. 


\section{Table of Contents}

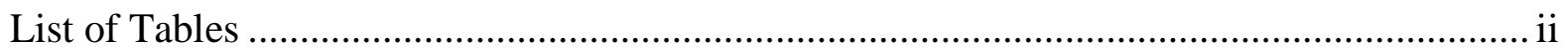

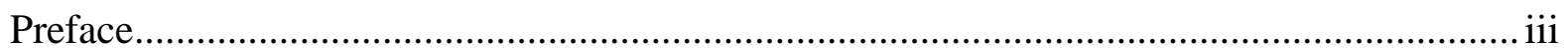

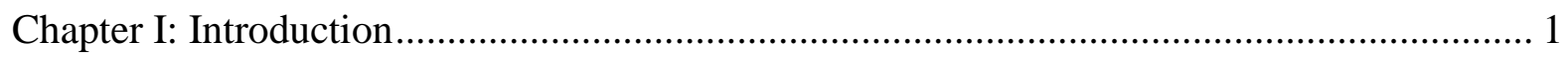

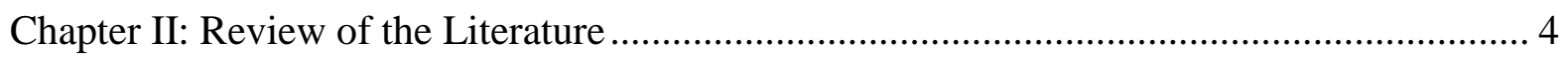

Individual and Community Responses to Trauma ........................................................... 4

The Museum as a Social Institution ............................................................................ 8

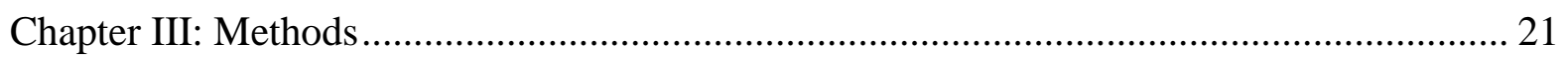

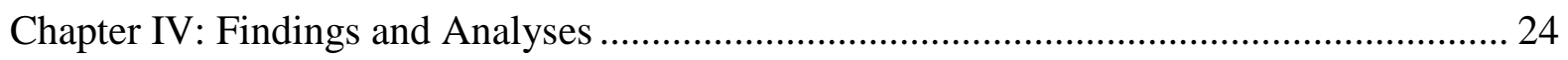

Document Analysis: The Event............................................................................. 24

The Oklahoma City Bombing................................................................................. 24

The Death of Michael Jackson ................................................................................... 25

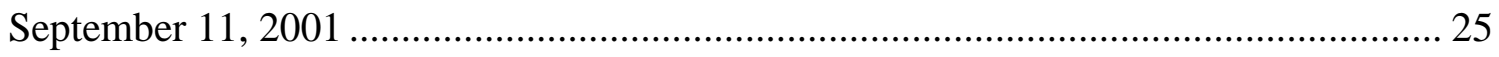

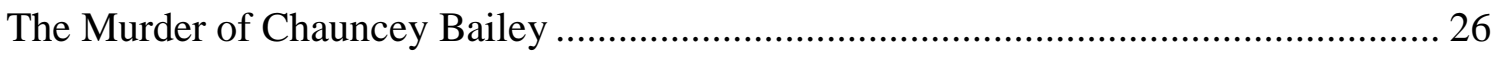

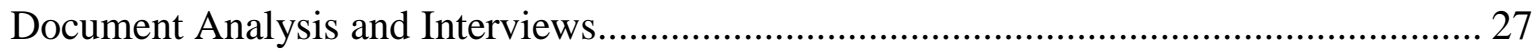

Document Analysis and Interviews: Museum Responses............................................... 27

The Oklahoma Museum Association's A Day for Children ………................................ 27

The Experience Music Project Museum and the Death of Michael Jackson .................. 28

The Field Museum and September 11, 2001 ............................................................... 29

The Oakland Museum of California and the Murder of Chauncey Bailey …….............. 31

Document Analysis and Interviews: Motivations of Staff ................................................. 34

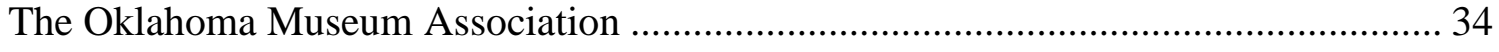

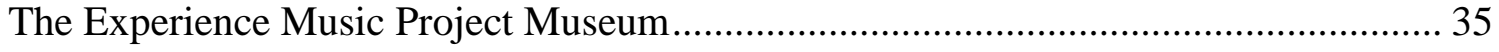

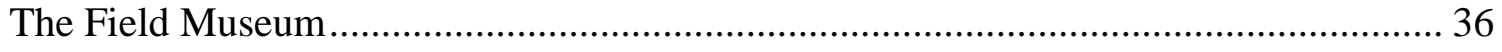

The Oakland Museum of California ............................................................................ 37

Program Characteristics in the Context of Healing Promotion............................................. 37

Chapter V: Conclusions and Recommendations................................................................. 47

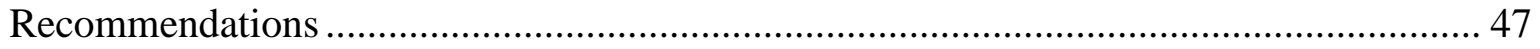

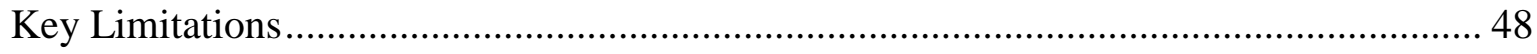

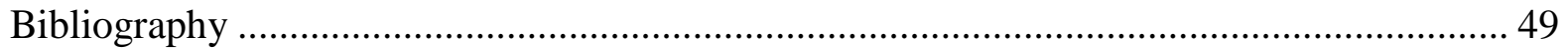

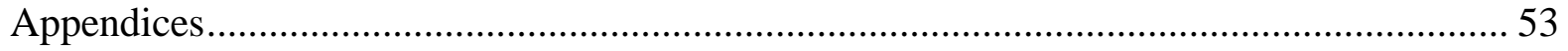

Consent form: Oakland Museum of California............................................................... 53

Consent form: Experience Music Project Museum.............................................................. 55 


\section{List of Tables}

Table I: Johnson's Response Continuum

Table II: The Oklahoma Museum Association and A Day for Children

Table III: The Experience Music Project Museum and the Death of Michael Jackson

Table IV: The Field Museum and September 11, 2001

Table V: The Oakland Museum of California and Days of the Dead celebration in Honor of Chauncey Bailey

Table VI: Case study comparisons: resources used

Table VII: Case study comparisons: components of healing 


\section{Preface}

When museum consultant Elaine Heumann Gurian visited the University of Washington Museology Graduate Program in October of 2011, she made a comment that when Princess Diana died in a car accident in 1997, museums in England did not see it as their responsibility to provide a space for the public to grieve and mourn the loss of their beloved monarch. As a result, memorials for the Princess sprang up in less than ideal spaces, which created a logistical nightmare for city officials. Public tributes were a threat to public safety; in front of Diana's home Kensington Palace, piles of flowers reached nearly five feet high and over one million bouquets were left. ${ }^{1}$ After her funeral, Kensington Palace was open to the public so that people could sign a condolence book for her family. As a result, tens of thousands of people waited in line for hours for their chance to leave their messages. ${ }^{2}$ Paired with the massive amount of objects placed at memorial sites, this response indicated a need by the public to grieve for Diana and work through the loss of someone they held dear.

It was this comment and curiosity regarding the phenomenon of public grieving that inspired this thesis research. In the Introduction to Museology course of the Museology Graduate Program, students are taught about the move into a more civic role of museums, a shift away from being solely about a collection toward being in the service of society. Some of the course's preliminary readings began to scratch the surface of the social service utility of museums, citing examples from the Great Depression, World War II, and in the aftermath of September 11, 2001 ("9/11"). The prospect that museums could serve as social service organizations and become spaces for meeting basic needs, such as the Lower Eastside Tenement Museum in New York

\footnotetext{
${ }^{1}$ Dick Gross, "Steve Jobs and the Marking of Death," The Sydney Morning Herald, 24 October 2011.

2 "Mourning Diana," Historic Royal Palaces: Kensington Palace, http://www.hrp.org.uk/KensingtonPalace/stories/dianasdeath (accessed 29 March 2012).
} 
City, which offered water, food, clean restrooms, and first aid to those walking uptown away from the World Trade Center site following the terrorist attacks of 9/11, was extremely moving. Other stories of how people flocked to museums to find refuge and comfort in the aftermath of the tragedy were also compelling. ${ }^{3}$ Why would people seek out a museum as a place to find solace? What is it about a museum that can help people feel better? These were the initial questions that guided this research.

While conducting this research, I saw images that took my breath away and read stories of overwhelming sadness. However, what resonated above all else was the hope that sprang up from the terror of these events and the incredible ways in which people came together to provide comfort and a direction at a time when it seemed impossible. The hope is that this research will help frame how museums can be of service at times when they are needed most. Rather than being paralyzed by fear when awful events occur, museums and their staff have the incredible opportunity to utilize their unique resources and rise to the occasion to provide for their audiences in ways that other organizations and institutions cannot.

\footnotetext{
${ }^{3}$ Ruth Abram, "When the Sky Falls: The Lower East Side Tenement Museum Responds to September $11^{\text {th }}$, History News, 57, no. 1 (Winter 2002): 8.
} 


\section{Chapter I: Introduction}

This thesis will seek to address how and why museums can be effective places to help resolve grief and transcend suffering in the aftermath of tragic events. The objective is to identify action patterns that can help inform museum practice.

By examining four case studies of contemporary museum responses to tragedy, answers and patterns may begin to emerge when addressing this question. Based on several criteria, the four case studies identified are:

1. The Oklahoma Museums Association's "A Day for Children" event following the bombing of the Alfred P. Murrah Federal Building

2. The Experience Music Project Museum's hosting of a tribute, memorial service, and encouraging audience expression following the death of musician Michael Jackson

3. The Field Museum's panel discussions, performances, and use of a permanent exhibit to interpret and understand the terrorist attacks of September 11, 2001

4. The Oakland Museum of California's annual Days of the Dead celebration as a tribute to slain journalist, Chauncey Bailey

Research was conducted in multiple disciplines including traumatology, psychology, grief studies and rituals, mental health, and sociology. This helped to frame the nature of grief, and how people embark on an intensely personal journey in order to resolve that grief, transcend suffering, and heal. It should be noted that the focus of this paper is on emotional healing in the aftermath of a tragic event. For these purposes, the research focused on events involving direct human action or life events that impact an entire community, whether on a local, national, or international scale. Communities are groups of individuals formed by people who have a 
common focus and/or common bond that brings them together. ${ }^{4}$ These bonds can be natural, such as geography or profession, or transitory, which can be bound by situation or a point in time. ${ }^{5}$ While natural disasters are certainly distressing and can be rife with grief, loss, and often devastating property damage or complete destruction, this research will focus on the aftermath of mass interpersonal violence, i.e. "intentional violence that involves high numbers of injuries or casualties, but does not occur in the context of war," ${ }^{\prime 6}$ and/or the sudden loss of an individual who was of particular prominence within a community. Following 9/11, history museums and historical societies in particular wrestled with the task of collecting objects that could be later used to interpret or memorialize the tragedy; ${ }^{7}$ however, the focus here is about museum institutional responses to tragedy that aid in the easing of suffering.

Throughout history, arts and cultural organizations have responded in times of duress. ${ }^{8}$ In the case of 9/11, the Cleveland Orchestra, instead of cancelling their scheduled performance, played for a concert hall filled to capacity. ${ }^{9}$ At the Metropolitan Museum of Art, over 8,000 visitors came to the museum when no blockbuster show was on display. ${ }^{10}$ During World War II, when all of London's public spaces were closed in the evenings to avoid visibility to German bombers, the National Gallery, having its collection cleared out and relocated to safer locations, began holding weekly lunchtime concerts that were so popular, what was intended to be a one

\footnotetext{
${ }^{4}$ Ellen S. Zinner et al., "The Connection Between Grief and Trauma: An Overview," in When a Community Weeps: Case Studies in Group Survivorship, ed. Ellen S. Zinner and Mary Beth Williams. (Philadelphia: Brunner/Mazel, 1999), 7.

${ }^{6}$ John Briere and Catherine Scott, Principles of Trauma Therapy: A Guide to Symptoms, Evaluation, and Treatment (Thousand Oaks, CA: Sage Publications, Inc., 2006), 5.

${ }^{7}$ James B. Gardner and Sarah M. Henry, "September 11 and the Mourning After: Reflections on Collecting and Interpreting the History of Tragedy," The Public Historian 24, no. 3 (Summer 2002): 37-38.

${ }^{8}$ Marjorie Schwarzer, Riches, Rivals \& Radicals: 100 Years of Museums in America (Washington: American Association of Museums, 2006), 14-15.

${ }^{9}$ Jim Collins, Good to Great and the Social Sectors (New York: Harper Collins, 2005$), 27$.

${ }^{10}$ Michael Kimmelman, "The Solace in Sharing the Beauty of Great Art and Music," New York Times, 17 September 2001.
} 
time performance ended up being a weekly event for over six years. ${ }^{11}$ There was also an examination of more personal examples of the positive effects that art and museums can have in supporting the grief process, particularly through acts of creation.

Unfortunately, tragic events are not rare and happen every day in a variety of magnitudes and scales. The ideal outcome of this research would be that the reader will gain a recognition of the ways museums can help people within their communities resolve grief, recover from tragedy, and restore balance, as well as provide a framework for current museum professionals to serve and benefit society as a whole.

\footnotetext{
11 "Myra Hess' Wartime Concerts," The National Gallery,
} http://www.nationalgallery.org.uk/paintings/history/myra-hess-concerts/the-myra-hess-concerts (accessed 9 February 2012). 


\section{Chapter II: Review of the Literature}

In conducting this research, it was necessary to establish a base of information spanning many disciplines. These disciplines included traumatology, psychology, grief studies and rituals, mental health, and sociology, as well as historical examples of when arts and cultural institutions have responded to their communities following tragedy. Only after providing context of how people react to trauma and which needs are common amongst individuals and communities who have experienced such trauma can this research further develop.

\section{Individual and Community Responses to Trauma}

The experience of trauma and resulting effects vary, though grief is a universal emotion. ${ }^{12}$ While much research exists on helping an individual deal with the aftermath of tragedy and resolution of grief, there are fewer resources that address the issue of healing an entire community.

Communities are groups of individuals formed by people who have a common focus and/or common bond that brings them together. ${ }^{13}$ These bonds can be natural, such as geography or profession, or transitory, which can be bound by situation or a point in time. ${ }^{14}$

Other terms that are important to clearly define are:

Crisis: a situation that individuals perceive as placing one in jeopardy ${ }^{15}$

Trauma: serious injury, wound or shock to the body or to the mind, often resulting in psychological and behavioral disorders ${ }^{16}$

Bereavement: the state of deprivation or loss ${ }^{17}$

\footnotetext{
${ }^{12}$ Lasse A. Nurmi and Mary Beth Williams, "Death of a Co-Worker: Conceptual Overview," in Death and Trauma: the Traumatology of Grieving, ed. Figley et al. (Washington: Taylor and Francis, 1997), 50-51.

${ }^{13}$ Ellen S. Zinner et al., "The Connection Between Grief and Trauma," 7.

${ }^{14}$ Ibid.

${ }^{15}$ Kendall Johnson, After the Storm: Healing After Trauma, Tragedy, and Terror (Berkeley: Hunter House, 2006), 70 .

${ }^{16}$ Zinner et al., "The Connection Between Grief and Trauma," 5.

${ }^{17}$ Ibid.
} 
Loss: the separation of an individual or group of individuals from a loved or prized object $^{18}$

Grief: the set of responses to a real, perceived, or anticipated loss ${ }^{19}$

Mourning: the cultural response to grief ${ }^{20}$

Healing: the personal experience of the transcendence of suffering ${ }^{21}$

Trauma and crises most often occur as a result of emergency situations which are serious, unexpected, and demand immediate attention. ${ }^{22}$ Because of these powerful factors, people are often propelled into fear, disorientation, uncontrollable behavior, or immobility. ${ }^{23}$ When further psychological trauma does occur, this phenomenon impedes grieving, ${ }^{24}$ which is a necessary component of healing. ${ }^{25}$ Grief is a universal response to death and loss, and can include a variety of behaviors, including sadness, crying, insomnia, disbelief, emotional numbness, nightmares, fatigue, loss of interest in activities, disorganization, anxiety, and despair. ${ }^{26}$ One model which describes the reaction to trauma is Kendall Johnson's Response Continuum ${ }^{27}$ :

Table I: Johnson's Response Continuum

\begin{tabular}{|c|c|c|}
\hline Position & What it feels like & How the world looks \\
\hline Shut down & No feeling & Disconnected, surreal \\
\hline Faded & Things don't seem important & Out of control \\
\hline
\end{tabular}

\footnotetext{
18 Ibid.

${ }^{19}$ Ibid.

${ }^{20}$ Ibid.

${ }^{21}$ Thomas R. Egnew, "The Meaning of Healing: Transcending Suffering," Annals of Family Medicine, no. 3 (May/June 2005): 258.

22 Zinner et al., "The Connection Between Grief and Trauma," 6.

23 Ibid.

${ }^{24}$ Ibid.

25 "School-Aged Children and Grief," The Healing Center, http://www.healingcenterseattle.org/children/childrensgrief/ (accessed 6 May 2012).

${ }^{26}$ Nurmi and Williams, "Death of a Co-Worker", 50-51.

${ }^{27}$ Johnson, After the Storm, 125.
} 


\begin{tabular}{|c|c|c|}
\hline Objective & Calm & Serious but understandable \\
\hline Fully present & Wide range, moderate feeling & Not good, but understandable \\
\hline Involved & Anger, fear, sadness & Dangerous \\
\hline Over reactive & Overwhelming feeling & Out of control \\
\hline Agitated & Unbearable feeling & Unendurable \\
\hline
\end{tabular}

When a person experiences a traumatic event, i.e., one that causes serious harm to the body or mind, this experience can destroy or dramatically alter an individual's world view and commonly held assumptions about the way the world "should" work. ${ }^{28}$ These commonly held assumptions include 1) the world is safe, 2) the world is predictable, and 3) bad things do not happen to good people. When these core principles are threatened, individuals are more likely to experience psychological distress. ${ }^{29}$

In order to overcome tragedy, a person must heal. Interestingly enough, it is difficult to find an operational definition of healing. ${ }^{30}$ A study of this phenomenon revealed three themes that contribute to a comprehensive definition of healing ${ }^{31}$ :

Wholeness - "To be whole as a person is to be whole amongst others. [The] wholeness of personhood as involving physical, emotional, intellectual, social, and spiritual aspects of human experience."32

Narrative - "Healing occurs within the life narrative of the person experiencing the phenomena...Healing is related to wholeness, and wholeness is experienced in connection with others...'bringing together' involves sharing vulnerability, which creates safety and fosters personal connection." 33

\footnotetext{
${ }^{28}$ Randal Beaton, "Psychosocial Responses to Biological and Chemical Terrorist Threats and Events: Implications for the Workplace - The aftermath of previous traumatic events can enlighten nurses about what to expect," AAOHN Journal : Official Journal of the American Association of Occupational Health Nurses, (50) no. 4 (2002): 185.

${ }^{29}$ Ibid.

${ }^{30}$ Egnew, "The Meaning of Healing," 255.

${ }^{31}$ Ibid., 257.

${ }^{32}$ Ibid.

${ }^{33}$ Ibid., 257-258.
} 
Spirituality - "A harmony' between mind, body, and spirit...With harmony comes health; therefore, spirituality is an important aspect of healing. Subthemes illuminating the theme of spirituality involved meaning, reconciliation, and transcendence... [and] seeking or discovering meaning in affliction." 34

Based on these three themes,

healing was defined in terms of developing a sense of personal wholeness that involves physical, mental, emotional, social and spiritual aspects of human experience. Suffering is transcended when invested with meaning congruent with a new sense of personal wholeness. Wholeness of personhood is facilitated through personal relationships that are marked by continuity. ${ }^{35}$

Ultimately,

'a healer...helps you make those connections between each other and everything around you'... healing [occurs] in contexts of 'real persons in connection with other real persons,' and...'to be whole is always to be whole in the presence of others.' Life narratives are social constructions, stories fashioned in connection with others. ${ }^{36}$

The purpose of a mourning period is to heal, recover, and regain equilibrium and the capacity to return to living fully. ${ }^{37}$ In order to mourn completely, individuals need an environment that supports grieving rather than inhibits it. ${ }^{38} \mathrm{~A}$ space where personal connections can be made can help to reduce the "loneliness that people feel. Narratives of healing are created in close...relationships that are personal in nature and supported by continuity..."39

Healing is not just "getting better", but is also the resolution of grief, whereby one returns to a normal level of functioning in everyday tasks, the absence of distress associated with grief,

\footnotetext{
${ }^{34}$ Ibid., 258.

35 Ibid.

${ }^{36}$ Egnew, "The Meaning of Healing," 257.

${ }^{37}$ Judy Tatelbaum, The Courage to Grieve, (New York: Harper and Row, Publishers, 1980), 22.

38 Ibid., 24.

${ }^{39}$ Egnew, "The Meaning of Healing," 258.
} 
and a change in identity to accommodate a new reality. ${ }^{40}$ It has been seen that strong social support, whether from the family or community, promotes a more rapid resolution of grief. ${ }^{41}$ When a traumatic event influences an entire community, healing can begin when that community is supported in collectively addressing the impact and consequences of tragedies in their lives and social networks. ${ }^{42}$

In summary, while communities experience tragedy and the resulting effects of trauma differently, ${ }^{43}$ trauma most often occurs as unexpected emergency situations. ${ }^{44}$ Due to these factors, there is a strong impact on individuals and communities. ${ }^{45}$ People must then work through the grief process, which is a necessary component of healing. ${ }^{46}$ Healing is the resolution of grief and occurs when an individual develops a sense of personal wholeness which "incorporates the experience of brokenness." 47 Grief can be resolved more rapidly and healing can commence when an individual has strong social support. ${ }^{48}$ When an entire community is engaged in the grief process, healing can occur when that community is supported in collectively addressing the impact and consequences the tragedy has in their lives and social networks. ${ }^{49}$

\section{The Museum as a Social Institution}

The International Council of Museums (ICOM) defines a museum as "a non-profit, permanent institution in the service of society...."50 This has not always been the professional

\footnotetext{
${ }^{40}$ John Archer, The Nature of Grief: The Evolution and Psychology of Reactions to Loss (New York: Routledge, 1999), 111.

${ }^{41}$ Archer, The Nature of Grief, 114.

42 Zinner et al., "The Connection Between Grief and Trauma," 5.

${ }^{43}$ Nurmi and Williams, "Death of a Co-Worker", 50-51.

${ }^{44}$ Zinner et al., "The Connection Between Grief and Trauma," 6.

${ }^{45}$ Ibid.

46 "School-Aged Children and Grief."

${ }^{47}$ Egnew, "The Meaning of Healing," 258.

${ }^{48}$ Archer, The Nature of Grief, 114.

49 Zinner et al., "The Connection Between Grief and Trauma," 5.

50 "Museum Definition," International Council of Museums, http://icom.museum/who-we-are/the-vision/museumdefinition.html (accessed 9 February 2012).
} 
definition of a museum, but this description has evolved over time, changing as the roles of museums have adapted and moved into the future ${ }^{51}$ Social worker Lois Silverman asserts that at their very core, museums are social institutions, and that there is a "growing belief among [museum] practitioners, policymakers, and the public alike in the power of museums to inspire hope and healing, improve lives, and better the world." 52 Indeed, museums have shifted from being about objects and the authoritative curatorial voice towards a more accessible and inclusive environment. ${ }^{53}$ Silverman asserts that "museums have long been considered institutions that benefit society, most familiarly through the activities of collecting, preserving, and education about valuable artifacts and art. Today, the world's museums are embracing starkly bolder roles as agents of well-being....,54

There are many reasons why a person may seek out a museum following tragedy, including the fact that

museums provide lasting touchstones for the validation of human tragedy, suffering, integration, and resilience. Through commemorations, rituals, exhibits, and other means, as opportunities for individuals with similar transcendence needs to link together for solidarity and support...museums provide societies with vehicles for public acknowledgement, memory, retribution, and transformation. ${ }^{55}$

Commemorations and rituals have long been coping mechanisms for the bereaved. ${ }^{56}$ Rituals are social gestures defined as a ceremony or a succession of ceremonies that are repeated time and again. ${ }^{57}$ The five fundamental human needs that are met by rituals are 1) establishing order, 2) reaffirming meaning, 3) bonding community, 4) handling conflicting emotions, and 5)

\footnotetext{
${ }^{51}$ Lois H. Silverman, The Social Work of Museums, (New York: Routledge, 2010), 2-3.

${ }^{52}$ Ibid., 2.

${ }^{53}$ Schwarzer, 100 Years of Museums in America, 2.

${ }^{54}$ Ibid.

${ }_{55}^{55}$ Ibid., 64-65.

${ }_{57}^{56}$ Archer, The Nature of Grief, 31.

${ }^{57}$ Jim Christiansen, "Rituals and Their Importance," in The Memorial Rituals Book for Healing and Hope, ed. Ann Marie Putter. (Amityville, NY: Baywood Publishing Company, Inc., 1997), 5.
} 
encountering mystery, such as addressing the belief of an afterlife or higher power. ${ }^{58}$ By "joining together, developing rituals and ceremonies, and talking about the [tragic] event over and over and thereby finding a forum for pain, survivors and their communities begin to heal. Rituals are frequently used to create a context and container for the expression of community feelings and to provide a focus on community healing [and] provide a way for communities to bring closure."59 It has been found that community healing can occur through a variety of community responses. ${ }^{60}$ Those response methods include

Cognitively: through discussion, planning, and education

Physically: action rituals, rest periods

Emotionally: through rituals, expression of feelings

Spiritually: through funeral ceremonies

Creatively: through the arts

Practically: through legal action, relocation, and physical resource development $^{61}$

Museums have unique resources which serve their communities. ${ }^{62}$ For example, viewing art in a museum reduces anxiety and contributes to emotional wellbeing. ${ }^{63}$ Museums are sometimes impromptu hosts of spontaneous memorials that occur immediately after a tragic event. ${ }^{64}$ Spontaneous memorials are an assemblage of objects, photos, and mementos in response to a crisis. ${ }^{65}$ These memorials provide a physical manifestation of grief where people can gather to cope, and "encourage disparate community members to communicate and collaborate, bond in

\footnotetext{
${ }^{58}$ Ibid.

${ }^{59}$ Zinner et al., "The Connection Between Grief and Trauma," 15.

${ }^{60}$ Ibid.

${ }^{61}$ Ibid.

${ }^{62}$ Elaine Heumann Gurian, "Timeliness," in Civilizing the Museum: The Collected Writings of Elaine Heumann Gurian, ed. Elaine Huemann Gurian. (New York: Routledge, 2006), 60.

${ }^{63}$ Jennifer Binnie, "Does Viewing Art in the Museum Reduce Anxiety and Improve Wellbeing?" Museums \& Social Issues 5, no. 2 (2010): 198.

64 "Museum Relevance: What I Learned from Michael Jackson," Museum 2.0, http://museumtwo.blogspot.com/search?q=jackson, (accessed 13 April 2012).

${ }^{65}$ K. Kroslowitz, "Spontaneous Memorials: Forums for Dialog and Discourse." Museums and Social Issues, no. 2 (2007): 244.
} 
shared emotions, establish new cultural identity, and to participate in history." ${ }^{66}$ One model of community healing in the aftermath of tragedy is George Everly's SAFE-R model:

1. The necessity of individuals in charge of a community to step back and take a visual break from disturbing imagery

2. Community leaders $\boldsymbol{a}$ cknowledge the crisis by providing open and honest factual information to the public

3. Community leaders facilitate an understanding of symptoms of acute stress that are likely to occur after crisis

4. Interventions are used to encourage adaptive coping

5. At the very least, minimal functioning is restored as community members stabilize ${ }^{67}$

Everly articulates that the first step in the healing of communities is the necessity for individuals in charge of the community to step away from imagery of the disaster and have time for a visual break. $^{68}$ It was observed that after the Oklahoma City Bombing, rescue workers who were inundated with the horrific task of pulling the deceased from the rubble, found that time spent away from the site interacting with survivors left them feeling rejuvenated and restored and better equipped to continue their work. ${ }^{69}$ In addition to rescue workers, families of survivors also not only face their personal tragedies, but are often exposed to media attention and public interest in their stories, which can complicate the grieving process by intruding on their privacy. $^{70}$

There are many documented instances wherein arts and cultural organizations have responded to a community in crisis. On an individual level, Chaim Potok, Rabbi and author, poignantly describes his relationship with museums while grappling with the harsh realities of the Holocaust from his home in New York:

\footnotetext{
66 Ibid.

${ }^{67}$ Zinner et al., "The Connection Between Grief and Trauma," 13.

68 Ibid.

${ }^{69}$ Karen A. Sitterle and Robin H. Gurwitch, "The Terrorist Bombing in Oklahoma City," in When a Community Weeps: Case Studies in Group Survivorship, ed. Ellen S. Zinner and Mary Beth Williams. (Philadelphia: Brunner/Mazel, 1999), 174.

${ }^{70}$ Ibid., 184.
} 
when I was young and casting about for ways to deal with the dark atmosphere of the then raging Second World War and the stupefying news of the annihilation of European Jewry that had begun to drift into our New York apartment, I discovered, among other marvelous things, the exquisite world of museums.... Those surroundings became for me a kind of second home, places in which to calm the troubled heart. ${ }^{71}$

Also during World War II, a long term example of people in arts and cultural institutions reaching out to their community occurred in London. Because of the threat to the public, most of London's public spaces were closed, including museums and galleries, and collections were shipped out of the city to safer locations. ${ }^{72}$ In the early days of this literal and "cultural blackout," the famed pianist Myra Hess approached then National Gallery director Kenneth Clark with the idea that a weekly concert be held in the gallery space. ${ }^{73}$ Clark and Hess shared the common belief that the "arts played a powerful spiritual role in the health of a nation" and could offer Londoners "comfort when they needed it most." 74 Indeed, Clark stressed the need that "the sooner we can start the better...this is the period when people are beginning to feel the need for want of nourishment for mind and spirit..." and Clark was delighted that the Gallery could "once again be used for its true purposes, the enjoyment of beauty." 75 The concerts were an overwhelming success. The first concert drew a crowd of 1,000, and many still were turned away. ${ }^{76}$ The atmosphere was casual and audience members were encouraged to eat their lunches and stroll in and out. ${ }^{77}$ The informality was further accentuated by the large crowd, as the 500 chairs originally set up were filled quickly, leaving just as many people to lean against the walls

\footnotetext{
71 “Comments By Chaim Potok," Facing History and Ourselves, http://www2.facinghistory.org/Campus/memorials.nsf/PrintView/DE9B4E8C4798B95385256ECF0070413 E?OpenDocument (accessed 16 February 2012).

72 "How the Concerts Started," The National Gallery, http://www.nationalgallery.org.uk/paintings/history/myra73 Ibid. hess-concerts/how-the-concerts-started (accessed 9 February 2012).

74 Ibid.

${ }^{75}$ Ibid.

${ }^{76}$ Ibid.

77 Ibid.
} 
or sit on the floor. ${ }^{78}$ Clark described the audience as "all sorts. Young and old, smart and shabby, Tommies in uniform with their tin hats strapped on, old ladies with ear trumpets, musical students, civil servants, office boys, busy public men, all sorts had come. ${ }^{, 79}$ Later, Clark said that hearing the "opening bars of Beethoven's Appassionata will always remain for me one of the great experiences of my life...it was an assurance that all our sufferings were not in vain." ${ }^{\prime 80}$ The concerts were a vital tool in boosting morale, and were "a sign that ordinary pursuits were still possible despite the circumstances, and an assertion that art and beauty would endure." ${ }^{\prime 81}$ From October 1939 to April 1946, daily concerts were held every week of the year, even during the worst of the Blitz, and were attended by a total of 750,000 people, including members of the Royal Family during the six year period. ${ }^{82}$ The late Queen Mother, Her Majesty Queen Elizabeth, once described her attendance at the National Gallery concerts as "some of the happiest hours she had known during the war. ${ }^{183}$

Similarly, following the days of the terrorist bombings of September $11^{\text {th }}$, the Cleveland Orchestra struggled with whether or not to change the program for the September $13^{\text {th }}$ concert, or to cancel the event all together ${ }^{84}$ Some wanted to alter the program to showcase patriotic music; others felt that the orchestra should cancel the evening's performance, in line with the majority of public events in America that week. ${ }^{85}$ Instead, the executive director and music director chose to go ahead with the evening's scheduled program, concluding "that perhaps more than any other week in history, people needed the orchestra to do the one thing it does supremely well: play the

\footnotetext{
78 Ibid.

${ }^{79}$ Ibid.

${ }^{80}$ Ibid.

${ }^{81}$ Ibid.

82 "Myra Hess' Wartime Concerts," The National Gallery, http://www.nationalgallery.org.uk/paintings/history/myra-hess-concerts/the-myra-hess-concerts (accessed 9 February 2012).

83 "How the Concerts Started."

${ }^{84}$ Jim Collins, Good to Great and the Social Sectors (New York: Harper Collins, 2005), 27.

${ }^{85}$ Ibid.
} 
most powerful orchestral music ever created by the human race." ${ }^{, 86}$ Every seat in Severance Hall was filled and each audience member bore witness to a powerful performance ${ }^{87}$ The orchestra's director felt that "there [was] absolutely nothing we could have done to be of better service at that moment." ${ }^{, 88}$

On September 17, 2001, less than a week after the tragedy of September $11^{\text {th }}$, the New York Times published an article about visitors to the Metropolitan Museum of Art in the days after the disaster. On the day of its reopening, 8,200 visitors came to wander the galleries. ${ }^{89}$ The reasons given as to why these people chose to go to a museum included replenishment, comfort, and beauty, as well as the opportunity to spend time with others. ${ }^{90}$ Human beings have a need to be social, but this doesn't necessarily mean interaction; being around others provides comfort and "is an antidote to loneliness." ${ }^{91}$ People found solace in continuity and the fact that beautiful art was still there, and found that being in a museum among company felt safe and normal - once common emotions that in recent days had felt particularly uncommon. ${ }^{92}$ Museums are about continuity in an ever and abruptly changing world, providing a place of solace and refuge. ${ }^{93}$ The executive director of the Met at that time, Phillipe de Montebello commented that

this is precisely the time we should be providing a comforting experience. People who haven't had the heart yet to go back to work have been coming here for a sense of serenity and the intercession of other people, rubbing shoulders in a kind of womb of culture. Hospitals are open. They're around to fix the body. We're here to fix the soul. ${ }^{94}$

\footnotetext{
${ }^{86}$ Ibid., 28.

${ }^{87}$ Ibid.

88 Ibid.

${ }^{89}$ Michael Kimmelman, “The Solace in Sharing the Beauty of Great Art and Music," New York Times, 17

90 Ibid. September 2001.

${ }^{91}$ Elaine Heumann Gurian, "A Savings Bank for the Soul," in Civilizing the Museum: The Collected Writings of Elaine Heumann Gurian, ed. Elaine Huemann Gurian. (New York: Routledge, 2006), 90.

${ }^{92}$ Kimmelman.

${ }^{93}$ Ibid.

${ }^{94}$ Ibid.
} 
As a safe gathering place, the museum encouraged "peaceful congregant behavior [which] is one of the essential elements of reestablishing community."95

Another example of response after 9/11 was a museum that has an internal infrastructure of being responsive: the Newseum, then located in Alexandria, Virginia. As the media reports of the terrorist attacks rolled in, museum staff worked through the night dually recording the news as it came in, as well as finding ways to present it to the public the following day. ${ }^{96}$ Those who put together the exhibit were journalists accustomed to creating a final product in a short amount of time, who in turn, informed staff trained in museum work that exhibitions could be developed overnight. ${ }^{97}$ Also using media as a medium to interpret breaking news was the National Air and Space Museum during the Columbia Shuttle explosion in 2003. Museum staff brought a television set into the gallery, and stationed "an expert to interpret the information for the public in real time." $" 98$

Lastly, using the museum as a gathering space open to the public, the Charles H. Wright Museum of African American History in Detroit, Michigan made its rotunda available for the laying-in-state of Coleman Young. ${ }^{99}$ Young was the first African American mayor of Detroit, and played an integral role in the establishment of the Museum. ${ }^{100}$ By making the space available, museum administrators helped to fill a "community need [and] strengthened the museum's ties to the community and extended its connections among people who had not visited the museum before."

\footnotetext{
${ }^{95}$ Gurian, "A Savings Bank for the Soul," 90.

${ }^{96}$ Gurian, "Timeliness," 61.

${ }^{97}$ Ibid.

98 Ibid.

99 Ibid.

100 "Today in Black History, 11/29/2011," Charles H. Wright Museum of African American History, http://www.thewright.org/component/content/article/1/560 (accessed 29 February 2012).

${ }^{101}$ Gurian, "Timeliness," 61.
} 
There is an important distinction between "facilities-based and content-based responses to crisis, ${ }^{, 102}$ meaning that museums can be somewhat passive yet still timely by opening up their doors and serving as public gathering spaces. ${ }^{103}$ Sociologist Ray Oldenburg emphasizes that informal gathering spaces are fundamental to the mediation between the individual and society, and that without such places, vital relationships amongst people cannot be nourished and cultivated. ${ }^{104}$ Museums have the valuable prospect for

the use of their safe spaces for strangers to congregate...When citizens feel threatened by terrorists (real or imagined), it becomes ever more important to find places and activities where groups can cross their own boundaries and recombine with others with some ease. In this context, all sides must see museums as fair and balanced venues. Museums must have many assets to work from. Most people perceive them as trustworthy and educative. They fall in the category of important civic venues... when the program appeals diversely to the visitor, when outside leadership declares the museum to be welcoming, when one finds the outing supportive and enlightening to one's family, when museums raise to accept the challenge of sustaining the community through unexpected catastrophes, the museum can, if it wants to, fulfill its broadest mission as a useful and engaging savings bank for the soul. ${ }^{105}$

While not developed in response to mass tragedy, the Museum of Broken Relationships in Zagreb, Croatia was created in order to give people the opportunity to "overcome an emotional collapse through creation: by contributing to the Museum's collection." ${ }^{106}$ The Museum was conceptualized out of the lack of formal ritual of a relationship's demise; by providing a sort of ritual, it is the hope that healing and closure can commence. ${ }^{107}$

\footnotetext{
102 Ibid., 60 .

103 Ibid.

${ }^{104}$ Ray Oldenburg, The Great Good Place: Cafes, coffee shops, community centers, beauty parlors, general stores, bars, hangouts and how they get you through the day (New York: Paragon House, 1989), xv.

${ }^{105}$ Gurian, "A Savings Bank for the Soul," 94-95.

106 “About the Museum of Broken Relationships," The Museum of Broken Relationships, ${ }^{107}$ Ibid. http://brokenships.com/en/about (accessed 20 February 2012).
} 
This similar act of healing through creation was emphasized in the exhibit Making Mends at the Bellevue Arts Museum in Bellevue, Washington. Artists presented work that focused "on the power of art to transcend grief and offer comfort" as well as to reveal "the motivations and very private struggles of [artists] working...to heal themselves and the world around them."108 The exhibit sought to examine and expose the similarities of the artists' works, as well as the "ritualistic, soothing, and meditative functionings of art.",109

Within weeks of the terrorist attacks of 9/11, a conference among public historians, entitled "The Role of the History Museum in a Time of Crisis" was held at the Museum of the City of New York (MCNY). ${ }^{110}$ Two primary issues were debated: if and how to collect objects for the future that could later be used to interpret the tragedy, as well as how to interpret the events in the moment in ways that were appropriate and sensitive. ${ }^{111}$ Both of these issues questioned history museums' responsibilities to the public. ${ }^{112}$ While many issues arose when contemplating these questions, ultimately, it was determined that it was "critical that [history museums] respond to...challenges thoughtfully and positively, embracing the opportunity to help our visitors understand these tragic events and [contribute] to the nation's healing.",113

It may be necessary for museums to be vital reactionary resources in order to maintain their relevance in society, as "relevant programs are inherently timely and responsive to community needs." Even the American Association of Museums' 1992 report, Excellence and

\footnotetext{
${ }^{108}$ Nora Atkinson, "From the Curator," in Making Mends exhibition catalogue, Bellevue, WA: Bellevue Arts Museum, 2012. ${ }^{109}$ Ibid.

${ }^{110}$ James B. Gardner and Sarah M. Henry, "September 11 and the Mourning After: Reflections on Collecting and 111 Ibid., 38 Interpreting the History of Tragedy," The Public Historian 24, no. 3 (Summer 2002): 38.

112 Ibid.

${ }^{113}$ Ibid., 52.
} 
Equity, called upon museums to serve communities as an integral part of professional practice. ${ }^{114}$ Museum consultant Elaine Heumann Gurian has stated that the ability of museums to react quickly and timely can contribute to the "societal usefulness" of museums. ${ }^{115}$ Because museums belong to a cadre of civic institutions that provide resources for community benefit, it would be necessary then for museums to "create new systems and reinvent [the] internal ethos." Museum staff are accustomed to creating exhibits that are thoughtful and reflective, though not always timely, thus this internal ethos change would involve a dramatic shift from traditional operations and would require inclusion in museum mission statements. ${ }^{117}$ If a museum has an institutional culture that allows for quick responses to community needs, a positive impact could be made in support of their audience. ${ }^{118}$ Therefore, museums who are successful in "breaking news are challenging themselves to find an appropriate balance between covering an event as news in an immediate and timely way and providing a reflective context that allows for thoughtful perspectives...[and] identifying the range of timely content and social roles they can undertake." ${ }^{\prime 19}$ Because museums are already poised to be of service during troubling times because of their unique resources, "a responsibility of museums is to use [these] unique resources in timely ways to build understanding of the challenges and opportunities we face, locally and globally." ${ }^{120}$

When museums are timely, they fill a leadership role within their community. If they do assume this role as community caretakers, museums can direct essential physical and emotional

\footnotetext{
${ }^{114}$ Edward P. Alexander and Mary Alexander, Museums in Motion: An Introduction to the History and Functions of Museums (New York: AltaMira Press, 2008), 283.

${ }^{115}$ Gurian, "Timeliness," 57.

${ }^{116}$ Ibid., 58.

${ }^{117}$ Ibid.

${ }^{118}$ Ibid., 60.

${ }^{119}$ Ibid., 62.

${ }^{120}$ Ibid., 60 .
} 
recovery efforts. ${ }^{121}$ Indeed, "vital to the success of many timely initiatives is the sustained engagement of communities... as partners with the institution and its programming...It ensures that programming is meaningful to the museum's constituents; builds a broad base of public support; draws in more diverse audiences; and directly contributes to the good of the community." 122

It is also entirely possible and beneficial for communities to help themselves, as "the natural caring processes can mobilize even in the greatest adversity. These responses can be nurtured through legitimization by key people, organizations, and interests through facilitation and mediation."123 The more successful institutional responses to tragedy often occur when partnerships and collaboration are utilized, and

the question, "how can we help you?" [is asked] is one of the most empowering for victim and helper alike. It involves and values the victim, while acknowledging and legitimizing the helper's skills and their proper mobilization. Through this act of partnership, control is being returned to those who have been disempowered and disabled by their experiences. ${ }^{124}$

It is important for community leaders to understand that the community's needs will change over time as the unique needs and challenges of survivors change over time. Museums should recognize that a reevaluation of community needs is essential in order to serve a community most effectively. ${ }^{125}$

In order for a museum to be poised to respond to issues in a timely manner, the following elements are critical:

- A fast and clear internal decision-making process

\footnotetext{
${ }^{121}$ Zinner et al., "The Connection Between Grief and Trauma," 7.

122 Gurian, "Timeliness," 64.

${ }^{123}$ David Bolton, "The Threat to Belonging in Enniskillen: Reflections of the Remembrance Day Bombing," in When a Community Weeps: Case Studies in Group Survivorship, ed. Ellen S. Zinner and Mary Beth Williams. (Philadelphia: Brunner/Mazel, 1999), 208.

${ }^{124}$ Bolton, "The Threat to Belonging in Enniskillen," 208.

${ }^{125}$ Sitterle and Gurwitch, "The Terrorist Bombing in Oklahoma City," 167.
} 
- Both the policy and courage to confront complex or controversial issues, including, specifically, governance that has comfortably and clearly delegated immediate decision making to the executive level

- Staff who are deployed or trained to implement exhibitions and programs quickly

- Internal systems that are designed and formatted to rapidly gather, process, present, and interpret related information

- An acceptance that works in progress can be publicly viewed and altered rather than fully rationalized prior to opening

- Prearranged collaborations with external organizations whose information base is deep and who are also organized and committed to be timely

- A public relations department with an ongoing cordial relationship with the media ${ }^{126}$

Gurian cites that museums, like archives, libraries, and sacred places, among others, can be considered "institutions of memory;" those institutions which "represent or store the collective holdings of the past." ${ }^{127}$ Institutions of memory "add to the stability of our society"128 and "all have a core purpose inherently important to our joint survival: we all need to be rooted in our collective past in order to face our collective future." 129

\footnotetext{
${ }^{126}$ Gurian, "Timeliness," 63.

${ }_{127}^{127}$ Gurian, "A Savings Bank for the Soul," 89.

${ }^{128}$ Ibid., 88-89.

${ }^{129}$ Ibid., 94.
} 


\section{Chapter III: Methods}

This research explores contemporary actions that museums have taken in order to provide emotional support and encourage healing for their audiences and within their communities. To demonstrate this, four case studies were identified. Each case study was then researched through a document analysis of media reports and primary source material. When possible, a staff member who was involved in the development of the case study program, exhibit, or event was identified and interviewed. This data collection sought to answer four questions: 1) What was the tragic event? 2) What did the museum do to respond to that event? 3) What were the motivations of staff to respond? and, 4) How could these museum actions contribute to the healing or resolution of grief for those who attended?

The case studies were selected based on the following criteria:

1. Each study explores how a museum reacted in the immediate (within 3 months) aftermath of a tragic event. For the purposes of this research, tragic events that were chosen involved direct human action or life events that impact an entire community.

2. Each case study program, exhibit, or event may have played a role in the healing or the resolution of grief among audiences.

3. Each case study was widely publicized and documented in the media, resulting in the availability and accessibility of data.

Based on this criteria, the four case studies selected were:

1. The Oklahoma Museums Association's "A Day for Children” event following the bombing of the Alfred P. Murrah Federal Building

2. The Experience Music Project Museum's hosting of a tribute, memorial service, and encouraging audience expression following the death of musician Michael Jackson

3. The Field Museum's panel discussions, performances, and use of a permanent exhibit to interpret and understand the terrorist attacks of September 11, 2001 
4. The Oakland Museum of California's annual Days of the Dead celebration as a tribute to slain journalist, Chauncey Bailey

Each case study was researched two-fold. The event itself was first researched through newspaper articles and reference material in order to fully understand the breadth and context of each event and the effects of that event on the community. The museum's actions were then researched, employing wide array of primary source materials. Examples included journal and newspaper articles, a radio program which included interviews with museum staff, and an examination of museum websites and social media pages, including Flickr and YouTube, which documented the specific actions taken by the museum.

When possible, a museum staff member who was involved in the development of the program, exhibit, or event was identified and interviewed, either in person or over the phone. Though variation occurred during the conversations, the interview questions consisted of:

1. At the time of (case study event), what was your title?

2. In the aftermath of (case study event), how did your museum respond?

3. What were the processes put into place by the museum to develop this program/exhibit/event? What drove you and other staff to take action?

4. Why did you and/or people at your institution feel it was necessary to respond to (case study event)?

5. What was the goal of this program/exhibit/event?

6. Did you ever consider or hope that your actions would help to promote healing in your community? Why?

7. Did you feel these actions were representative of your responsibilities as a museum professional or your institution's position in the community?

8. Do you think these programs were successful? Why so? Was an evaluation done?

9. Is there anything else you would like to add? 
Two people were identified, contacted, and participated in an interview session. One individual from the Experience Music Project Museum participated in an in person interview. The other individual from the Oakland Museum of California was interviewed over the phone. The interviews were informal and conversational and provided additional insight into the museum's activities, and further informed the museum's response to the case study event and motivations of staff. These conversations and quotations enriched this study and will be included and noted in the findings as this paper progresses. These conversations did not merit a formal presentation of findings through a complete transcript.

The interview questions and procedures were granted Exempt status by the University of Washington's Institutional Review Board. Each participant was provided with a consent form (see Appendices) outlining the study information and purpose, and was free to refuse to answer any question or opt out of the study at any time. As per the consent form agreement, staff will be referenced by first name, general title, and institution. One interview was audio recorded with permission from the interviewee, and destroyed upon completion of this research. 


\section{Chapter IV: Findings and Analyses}

\section{Document Analysis: The Event}

\section{The Oklahoma City Bombing}

On April 19, 1995, a homemade bomb made from fertilizer, fuel oil, and other chemicals located within a rented moving truck exploded in front of the Alfred P. Murrah Federal Building in Oklahoma City, Oklahoma. ${ }^{130}$ The blast was so powerful that it dissolved the north side of the building and created an instantaneous cavern from the street to the roof of the nine-story structure. ${ }^{131}$ Prior to the events of September 11, 2001, the Oklahoma City Bombing was the most deadly terrorist bombing in United States history. ${ }^{132}$ The mastermind of the plot was exArmy soldier and anti-government activist, Timothy McVeigh. ${ }^{133}$

A total of 168 people were killed as a direct result of the explosion, including 19 children.

Of those 19 children, 15 had been in the daycare center located within the Murrah Federal Building, and 4 had been visiting the building with relatives. ${ }^{134}$ Of all the children who had been in the Murrah Building's daycare center, only 5 survived. In addition to the daycare center in the Murrah Federal Building, a nearby Young Men's Christian Association (YMCA) daycare center was affected, injuring 52 children. ${ }^{135}$ Due to the death toll of adults in the blast, thirty children were orphaned and 219 children lost one parent. ${ }^{136}$ Because of these facts, much media attention focused on the effect the attacks had on children, particularly after the striking photograph of firefighter Chris Fields holding the body of one year old Baylee Almon was published on front

\footnotetext{
130 “Terror Hits Home: The Oklahoma City Bombing," Federal Bureau of Investigation, http://www.fbi.gov/aboutus/history/famous-cases/oklahoma-city-bombing (accessed 1 April 2012).

${ }^{131}$ Sitterle and Gurwitch, "The Terrorist Bombing in Oklahoma City," 161.

132 “Oklahoma City Bombing vs. Sept. 11,” CBS News, http://www.cbsnews.com/2100-500164_162-550231.html

133 Ibid. (accessed 1 April 2012).

${ }^{134}$ Sitterle and Gurwitch, "The Terrorist Bombing in Oklahoma City," 163-164.

${ }^{135}$ Ibid., 164.

${ }^{136}$ Ibid.
} 
pages of newspapers throughout the world and soon became an iconic image of the tragedy. ${ }^{137} \mathrm{~A}$ survey of area Oklahoma City schoolchildren indicated that almost all knew at least one person who was injured or killed in the explosion. ${ }^{138}$

\section{The Death of Michael Jackson}

In late June of 2009, musician Michael Jackson died unexpectedly of cardiac arrest in Los Angeles, California at the age of 50. ${ }^{139}$ Jackson had been influential in the world of music since he was 11 years old, resulting in nearly four decades in the entertainment business. ${ }^{140}$ His multifaceted talents were reflected in his wins of several different Grammy Awards including Best Rhythm and Blues Song for "Billie Jean," Best Male Pop Vocal Performance for "Thriller," and Best Male Rock Vocal Performance for “Beat It."141 Jackson's death was met with an outpouring of grief and sympathy, including a large celebration at the event arena in his hometown of Gary, Indiana. ${ }^{142}$ In July of 2009, a memorial for Jackson was held in the Staples Center in Los Angeles. ${ }^{143}$ A total of 17,500 tickets were available via a lottery system, but it is estimated that more than one billion people watched the service on television or the Internet. ${ }^{144}$

\section{September 11, 2001}

On September 11, 2001, the United States fell victim to a calculated and multi-pronged terrorist attack. Terrorists from the Islamic extremist group, al Qaeda, hijacked four commercial

\footnotetext{
137 “Those Who Were Killed: Miss Baylee Almon,” Oklahoma City National Memorial and Museum, http://www.oklahomacitynationalmemorial.org/secondary.php?section=1\&ordering=5\&catid=24 (accessed 26 March 2012).

${ }^{138}$ Sitterle and Gurwitch, "The Terrorist Bombing in Oklahoma City," 166.

139 "Michael Jackson,” Biography, http://www.biography.com/people/michael-jackson-38211?page=1, (accessed 30 140 Ibid.

${ }^{141}$ Ibid.

142 Ibid.

143 Ibid.

${ }^{144}$ Ibid.
} 
airplanes as part of a suicide mission. ${ }^{145}$ The targets of this attack included the World Trade Center towers in New York City and the Pentagon in Washington, DC, which were symbolic targets of America's economic prosperity and military power. ${ }^{146}$ It is believed that the fourth plane was intended to crash into the United States Capitol building, the center of American government, however passengers on that flight thwarted the attack and the plane crashed in a field in western Pennsylvania. ${ }^{147}$ As a result of the terrorist attacks, nearly 3,000 lives were lost. $^{148}$

\section{The Murder of Chauncey Bailey}

Chauncey Bailey was a prominent figure in Oakland's local news scene and a veteran of television, radio, and print media. ${ }^{149}$ While walking to his office at The Oakland Post one August morning in 2007, Bailey was confronted by a young man in a ski mask who shot Bailey three times, killing him. ${ }^{150}$ It was later revealed that Bailey was targeted because he was working on a story exposing the serious financial problems of the Your Black Muslim Bakery, problems which were the result of years of fraud, embezzlement, and forgery. ${ }^{151}$ The Your Black Muslim Bakery had been active in the community for many years, and while it provided jobs to many in the Oakland area, it was also known for its intimidation tactics and criminal activity. ${ }^{152}$

\footnotetext{
145 “FAQ About 9/11," National September 11 Memorial and Museum, http://www.911memorial.org/faq-about-911 146 Ibid. (accessed 11 May 2012).

147 “FAQ About 9/11,” National September 11 Memorial and Museum, http://www.911memorial.org/faq-about-911 (accessed 11 May 2012).

148 “9/11 Attacks,” History.com, http://www.history.com/topics/9-11-attacks (accessed 1 April 2012).

149 “Chauncey Bailey," The Chauncey Bailey Project, http://www.chaunceybaileyproject.org/about/chauncey-bailey/ (accessed 2 April 2012).

150 “The Murder of Chauncey Bailey,” CBS News, http://www.cbsnews.com/2100-18560_162-3861939.html

151 Ibid. (accessed 16 March 2012).

152 Ibid.
} 


\section{Document Analysis and Interviews}

The following two sections will address each case study museum's institutional response to tragedy and the motivations of staff. When conducting the research methods of document analyses and interviews, data relating to these two components was revealed. One in person interview and one phone interview with staff were completed at the Experience Music Project Museum and Oakland Museum of California, respectively. Their comments are included in the following two sections. As per the consent agreement, interviewees will be referred to by first name, general title, and institution.

\section{Document Analysis and Interviews: Museum Responses}

\section{The Oklahoma Museum Association's A Day for Children}

The fact that Oklahoma City was a particularly close-knit community and the bombing had a significant impact on children inspired the event, "“A Day for Children,' a cooperative effort among Oklahoma City's museums to give local kids a much-needed respite from the sorrow and upheaval that [had] pervaded their lives since the disaster." ${ }^{\prime 53}$ Museum educators at the Kirkpatrick Center, a complex that houses several museums including the Center of the American Indian, the International Photography Hall of Fame and Museum, the Oklahoma Air \& Space Museum, and the Omniplex Science Museum, ${ }^{154}$ worked in collaboration with staff at the Oklahoma Museums Association to coordinate the event. ${ }^{155}$ In all, sixteen institutions participated in A Day for Children - some by offering special programming and free activities such as a storyteller and clown who created balloon animals, a harpist who performed songs from Disney movies, an F-16 flight simulator at the Oklahoma Air and Space Museum, and a

\footnotetext{
${ }^{153}$ Susannah Cassedy O’Donnell, “The Muse of Good Will in Oklahoma City,” Museum News, no. 74 (1995): 10.

154 “Oklahoma City Attractions,” Planet Ware, http://www.planetware.com/tourist-attractions-/oklahoma-city-us-okokc.htm (accessed 1 April 2012).

155 O’Donnell, “The Muse of Good Will in Oklahoma City,” 10.
} 
tree planting ceremony using the same shovel used by President Bill Clinton when planting a tree in Washington, DC to commemorate victims of the bombing. ${ }^{156}$ Other museums that participated by offering free admission to children under 12 were the National Cowboy Hall of Fame and Western Heritage Center, the Amateur Softball Hall of Fame, the Harn Homestead Museum, the Oklahoma Firefighters Museum, and the State Museum of History. ${ }^{157}$

\section{The Experience Music Project Museum and the Death of Michael Jackson}

The Experience Music Project Museum (EMP) in Seattle opened in 2000 and has a mission that expresses dedication "to the ideas and risk-taking that fuel contemporary popular culture. With its roots in rock and roll, EMP serves as a gateway museum, reaching multigenerational audiences through... collections, exhibitions and educational programs..."158 On the day of Michael Jackson's death, within minutes of media reports breaking the news, the Experience Music Project Museum was contacted by a local Seattle news outlet as a source to tell about the reaction to his death. ${ }^{159}$ This barrage of press coverage resulted in the museum going into high gear to create a community space for mourners to come and celebrate Jackson. ${ }^{160}$ In its collection, the museum had one of Jackson's famous gloves, which had been on display once before, and the jacket he wore at "Motown 25," the $25^{\text {th }}$ anniversary of Motown celebration, where he first performed his iconic dance, the Moonwalk. ${ }^{161}$ These objects were put on display in the Sky Church, an area of the museum that is accessible for free to the public, ${ }^{162}$

\footnotetext{
156 Ibid., 11.

${ }^{157}$ Ibid.

158 "Vision and Mission," Experience Music Project Museum,

http://www.empmuseum.org/aboutEMP/index.asp?categoryID=285, (accessed 30 March 2012).

159 Jacob , personal interview with author, Seattle, WA, 8 March 2012.

161 Ibid.

162 Ibid.
} 
and houses the world's largest indoor LED screen. ${ }^{163}$ The following day, EMP had the $25^{\text {th }}$ anniversary of Motown celebration on view in the Sky Church, and the next week hosted a viewing of Michael Jackson's memorial service to an at-capacity crowd. ${ }^{164}$ In addition to the events playing on the Sky Church screens, an event staff member had placed sidewalk chalk out in front of the museum, and the public were invited to write their comments. These comments later covered the entire cement area in front of the museum. ${ }^{165}$ Inspired by this phenomenon, butcher paper and markers were made available on the inside of the museum where visitors could leave messages. ${ }^{166}$

Two women, who met while standing in line waiting to watch the memorial on the live feed at the museum, said that even though they could have watched the memorial at home, they were grateful to have a place to go and wanted to be in the presence of other fans. ${ }^{167}$

\section{The Field Museum and September 11, 2001}

The Field Museum in Chicago responded to the events of 9/11 in several different ways. These included hosting concerts, a theatrical performance, and utilizing an already existing permanent exhibit within the museum, Living Together. The centerpiece of the museum's program was the organization of three town hall style meetings intended to "help the public put the tragedy in historical perspective and consider the question, 'where do we go from here?"”168

\footnotetext{
163 "Private Events at EMP SFM," Experience Music Project Museum, http://www.empmuseum.org/documents/privateEvents/PrivateEventsAtEMPSFM.pdf, (accessed 30 March 2012).

${ }^{164} \mathrm{Jacob} \_$_ personal interview with author.

165 Ibid.

166 Ibid.

167 "Fans Gather at EMP to Remember Jackson,” KIRO TV Seattle, http://www.kirotv.com/news/news/fans-gatherat-emp-to-remember-jackson/nKXJK/ (accessed 30 March 2012).

168 Jane Lusaka, "Community Gathering: A Report from the Field," Museum News 80, no. 6 (November/December 2001): 37.
} 
The panel discussions were conceptualized following a staff meeting which was held on September $12^{\text {th }}$, the day after the tragedy. At the staff meeting, employees gathered to discuss if and how and if the museum should respond, and staff were given the chance to ask questions about the attacks, dispel misinformation, and gather and be in the company of others. ${ }^{169}$ Later, while discussing the museum's responsibility to the public, the staff was inspired by the helpfulness of the internal staff meeting and decided to organize a public town hall. ${ }^{170}$ Over the next two weekends, three panel discussions were held. ${ }^{171}$ Panelists were identified both within the museum, such as anthropologists whose area of expertise was the Middle East, and externally from area universities, and religious and cultural organizations. ${ }^{172}$ Community members had the opportunity to discuss and ask questions about a variety of issues, including putting war into historical perspective, the history of the Middle East, perceptions of America and Americans throughout the world, religion, issues of terror, and positive ways to take action. ${ }^{173}$ Of all the events that took place at the museum in the two weekends following $9 / 11$, museum staff highlighted how the museum called on already existing community partnerships with universities, religious organizations, and cultural organizations that helped both publicize the activities, and had a shared hand in organizing the events. ${ }^{174}$

In addition to the panel discussions, other facilities at the museum were utilized. Staff saw a rise in popularity in the permanent exhibition, Living Together, an exhibit on cultural diversity, that when "reduce[d] to one sentence, is: common concerns, different responses."175 While the exhibit had been on display for four years and was often passed over by visitors who

\footnotetext{
${ }^{169}$ Ibid.

${ }^{170}$ Ibid.

${ }^{171}$ Ibid.

${ }^{172}$ Ibid., 62.

${ }^{173}$ Ibid.

${ }^{174}$ Ibid., 63-64.

${ }^{175}$ Ibid., 63.
} 
were interested in other shows, it took on new meaning in the wake of $9 / 11 .{ }^{176}$ Other events included a concert in Field Hall by the Chicago Children's Choir and a theater performance entitled Surviving Violence. ${ }^{177}$

\section{The Oakland Museum of California and the Murder of Chauncey Bailey}

Near where Chauncey Bailey died is the Oakland Museum of California (OMCA), which was established in 1969 as a "museum for the people."178 OMCA has long valued community engagement as part of its practice, and the annual Days of the Dead celebration at the museum was in fact a product of the museum's community partnerships. ${ }^{179}$ The museum's Latino Advisory Council presented the idea for the museum to host a Day of the Dead celebration in the East Bay area where there is a high percentage of Latino residents. ${ }^{180}$ The event began in 1994 as an exhibit and community celebration orchestrated by the museum's education department, and has since become the largest annual event hosted by OMCA. ${ }^{181}$ To put on the two-month long program, museum educators "partner with local artists, community members, and outside curators as guest curators, and these guests assemble diverse artists, school groups, and community members to build shrines, or ofrendas, as offerings to the dead."182 Evelyn, a Project Director at the museum, notes that the Days of the Dead celebration is valuable because

the topic of death transcends culture or ethnicity. It's something we all grapple with. And here is an educational institution providing you a safe way to gather tools to grieve. The exhibition has a real intimacy that you get right away - about your mom who died, or your child. The instant level of intimacy from the subject adds this whole other closeness between

\footnotetext{
${ }^{176}$ Ibid.

${ }^{177}$ Ibid, 65.

178 “About the Oakland Museum of California," The Oakland Museum of California, http://museumca.org/about (accessed 2 April 2012).

${ }^{179}$ Nina Simon, The Participatory Museum (Santa Cruz: Museum 2.0, 2010), Chapter 8:

${ }^{180}$ Ibid. http://www.participatorymuseum.org/chapter8/.

${ }^{181}$ Evelyn ___ phone interview with author, 5 April 2012.

${ }^{182}$ Simon, The Participatory Museum, Chapter 8.
} 
the museum, participant, and the viewer. It's a program that makes people feel like this is their place, their museum, and there's a sense of ownership. ${ }^{183}$

The origin of the Day of the Dead holiday has its roots both in Mesoamerica and Catholicism, and involves creating an altar or sacred space to honor those who have died. ${ }^{184}$ Traditionally there are many different styles of altars, but OMCA has typically followed the Oaxacan style which incorporates marigold flowers, candles to help guide the spirit home, water for the spirits on their journey, photos of the deceased, their favorite foods, and their favorite objects. ${ }^{185}$ The holiday is a way to annually remember the lives of those who have passed. ${ }^{186}$ Evelyn maintains that the holiday is not a celebration of death, but rather a celebration of the lives of those who are no longer physically on earth, and she feels that the Day of the Dead provides a healthy way to mourn and a way to continue the healing process. ${ }^{187}$ Rituals like creating an altar or cooking the favorite foods of the departed and recalling stories about them honors the dead, and in some ways keeps them alive. ${ }^{188}$ People have a need to heal and grieve, but the celebration also empowers individuals to think about how they will be remembered by their families and how best to live their lives. ${ }^{189}$

In 2007, the museum rapidly responded to the death of Chauncey Bailey by incorporating a tribute to him as part of the annual Days of the Dead celebration. Bailey was murdered just a few blocks from OMCA and the event was a very visible tragedy which had a tremendous impact on Oakland. ${ }^{190}$ The theme of that year's Days of the Dead celebration was Ancient

\footnotetext{
${ }^{183}$ Ibid.

184 “The Morning Show - October 11, 2007 at 7:00am," KPFA Radio Berkeley,

185 Ibid. http://www.kpfa.org/archive/id/7291 (accessed 16 March 2012).

186 Ibid.

${ }^{187}$ Ibid.

188 Ibid.

${ }^{189}$ Ibid.

${ }^{190}$ Evelyn ___ phone interview with author, 5 April 2012.
} 
Roots/Urban Journeys: Expressions for Dias de los Muertos which examined traditional ways that ancestors are honored fused with modern ways to honor the dead. ${ }^{191}$ Each year, a guest curator orchestrates the exhibit, and that year's curator, Anje Helstrup-Alvarez "encouraged artists to reinterpret the spiritual holiday. Ancient Roots/Urban Journeys includes Days of the Dead imagery and expressions from pre-colonial Mesoamerica (Oaxacan-style altars) to its contemporary Californian configurations (mixed media and graffiti art)." ${ }^{, 192}$ The 2007 Days of the Dead celebration was two-part: an exhibition within the museum that addressed the phenomenon of street altars, including that which was erected at the site of Bailey's murder, and a one day community celebration at which artists created an offering altar or ofrenda honoring Chauncey Bailey. ${ }^{193}$

At the site of Bailey's murder, a memorial to the journalist was formed and evolved in the days following his death. Evelyn had documented the memorial each day, and photos of the memorial were later added to the exhibit at OMCA. ${ }^{194}$ This was a recognition of the altar created at the site of Chauncey Bailey's death, but not an exact replica. ${ }^{195}$ Also within the exhibition was a comment book in the exhibit where visitors could leave their messages for or about Chauncey Bailey. ${ }^{196}$

The second component to the OMCA Chauncey Bailey tribute was a one day community celebration in October 2007. Seven African American artists created ofrendas in the museum's gardens that paid homage to Chauncey Bailey and his legacy. ${ }^{197}$ The concept of the offering altar was two pyramid structures which incorporated a multimedia approach to the surface of the

\footnotetext{
191 Ibid.

192 “Ancient Roots/Urban Journeys: Expressions for Dias de los Muertos," The Oakland Museum of California, http://museumca.org/exhibit/exhi_days_of_dead.html (accessed 9 April 2012).

193 "The Morning Show - October 11, 2007 at 7:00am."

${ }^{194}$ Ibid.

${ }^{195}$ Evelyn ___ phone interview with author, 5 April 2012.

196 Ibid.

197 “The Morning Show - October 11, 2007 at 7:00am.”
} 
pyramids with photos and news articles of Bailey's. ${ }^{198}$ The intent was to honor Bailey's legacy of freedom of speech, activism, empowering communities, particularly African American communities, and encouraging all people to participate in democratic processes of government. ${ }^{199}$ Also within the community celebration was a portrait painting of Bailey which used tones of blue to symbolize tranquility, calmness, and an association with heaven. ${ }^{200}$ The Days of the Dead celebration was a way to invite the community in and have them be a part of celebrating the life of Chauncey Bailey and inspire others to continue the legacy of his work. ${ }^{201}$ The community celebration in the museum's gardens was free to the public, and audiences could take advantage of half-price admission that day to view the exhibition within the museum. ${ }^{202}$

\section{Document Analysis and Interviews: Motivations of Staff}

\section{The Oklahoma Museum Association}

The "Day for Children" activities was not intended to deal directly with the bombing, but rather to provide a distraction from the tragedy and to help children regain a sense of normalcy. ${ }^{203}$ Programs in schools and churches were already facilitating discussions about the terrorist attack, and the museums involved in A Day for Children "wanted to make it more of a day of healing." 204 One staff member emphasized the importance that the Oklahoma City museum community reassure children that museums are safe places run by trusted adults and to reinforce the message that there are good people in the world. ${ }^{205}$

\footnotetext{
${ }^{198}$ Ibid.

${ }^{199}$ Ibid.

${ }^{200}$ Ibid.

${ }^{201}$ Ibid.

${ }^{202}$ Ibid.

${ }^{203}$ O'Donnell, "The Muse of Good Will in Oklahoma City," 10.

${ }^{204}$ Ibid.

${ }^{205}$ Ibid., 11-14.
} 


\section{The Experience Music Project Museum}

At EMP, Jackson's glove and jacket became the focal point of the celebration. Sharing these extremely prominent objects from the collection with the public was important because it meant that

the audience can really get close to something that really was Michael's. I think that's what our museum really thrives off of, unlike an art museum, you'll have an emotional connection to the artwork but a lot of it is this intellectual connection. With our material, it's primarily emotional. When people see Jimi Hendrix's guitar, [when] they see Michael's glove, it's more about their direct connection to the objects and what those objects represent. It's their story. It's interesting, I feel our audience is unique in that way. Those objects really acted as a focal point for the whole celebration and what we did. ${ }^{206}$

Jacob, a curator at EMP, stated that it was important to create a space where Jackson and

his legacy could be celebrated, and that Jackson was an artist who was extremely influential and prominent in music for several decades. ${ }^{207}$ His success in breaking the racial barrier, his unique crossovers between rhythm and blues, soul, and pop became the focus. ${ }^{208}$

When determining how EMP would respond, the question for Jacob became "what can we do, with the resources and time available to us?"209 Even though all of these events and programs came together rapidly, Jacob said that everything was "so unplanned, I wouldn't even call it a program. I would call it a gut-level response." ${ }^{210}$ The fact that EMP recognized that the passing of Jackson, who was such a prominent figure in music, was a historical event helped propel the museum forward in taking action. ${ }^{211}$

\footnotetext{
${ }^{206}$ Jacob , personal interview with author.

${ }^{207}$ Ibid.

${ }^{208}$ Ibid.

${ }^{209}$ Ibid.

${ }^{210}$ Ibid.

${ }^{211}$ Ibid.
} 


\section{The Field Museum}

Museum staff were initially motivated to be of service to their community after an internal meeting gave staff the opportunity to talk about the tragedy. ${ }^{212}$ Mary Ellen Munley, then the museum's director of education stated that she couldn't

imagine any other place in a city that could have brought together scholars, community leaders, children, families, and resources, such as the public library [at the museum] or imagine any other place that would bring that many people together and allow them to do the things that they wanted-anything from concerts to a book display to the town hall...to the galleries to a theater performance.

Manager for performing arts and lectures at the Field, Encarnacion Teruel mirrored those sentiments and was quoted as saying

...we had a responsibility to serve the community of Chicago. We have these resources here, whether they're our exhibitions and halls and programs exploring cultural diversity, or a diverse array of partners within the city of Chicago. But I think it took us to another level, and it presented an expansion of the role of museums. Since September 11, we really are living in a new world. And we have a new understanding of the role that a museum can play in people's lives and how vital that is to people's lives. $^{213}$

The Field's multi-pronged response efforts were intended to create a gathering place for community members, and staff felt that they needed to rise to the occasion to be of service to their communities. $^{214}$

Teruel said that the museum's intent was to provide "context [and] a deeper understanding around a lot of the issues that we've been exposed to since September $11^{\text {th }}$.,215 Staff members had hoped that by offering free admission (made possible by quickly securing very willing sponsors), the museum could be opened to the community "for people to use it in

\footnotetext{
212 Jane Lusaka, "Community Gathering: A Report from the Field," Museum News 80, no. 6 (November/December 2001): 37.

${ }^{213}$ Ibid., 64.

214 Ibid., 37.

215 Ibid.
} 
whatever way they wanted...the museum could serve as a place for people who were looking to get away from the television. We wanted to let people go into the galleries and be in the presence of other human beings. ${ }^{216}$

\section{The Oakland Museum of California}

Evelyn commented that the actions of the museum were representative of both OMCA's and her personal commitment to serving the Oakland community. ${ }^{217}$ She noted that the museum has the resources of the Days of the Dead celebration and the space to provide a place for healing, something that is less common in Western cultures, which do not always place an emphasis on the healing process. Because OMCA had the tools to help their community, the museum should be available to help their audience work through the grief process. ${ }^{218}$

\section{Program Characteristics in the Context of Healing Promotion}

By drawing from the research included in the Literature Review, there can be an analysis of each case study in the context of healing promotion. Based on this research, the following are components of healing, ways in which grief is resolved, or tools and actions that contribute to both healing and the resolution of grief after tragedies:

1. Personal connections which are supported by continuity and help to develop a sense of personal wholeness ${ }^{219}$

2. Rituals or ceremonies that provide a forum for the expression of emotion and provide a focus on healing and closure 220

3. Acts of creation, such as spontaneous memorials, which are physical manifestations of grief ${ }^{221}$

4. The necessity to take a visual reprieve from disturbing imagery of a tragedy $^{222}$

\footnotetext{
${ }^{216}$ Ibid., 62-63.

${ }^{217}$ Evelyn ___ phone interview with author, 5 April 2012.

${ }^{218}$ Ibid.

${ }^{219}$ Egnew, "The Meaning of Healing," 258.

${ }^{220}$ Zinner et al., "The Connection Between Grief and Trauma," 15.

${ }^{221}$ Kroslowitz, "Spontaneous Memorials," 244.

${ }^{222}$ Zinner et al., "The Connection Between Grief and Trauma," 13.
} 
5. Strong social support from the family or community, which collectively address the impact and consequences of tragedy ${ }^{223}$

6. When community leaders respond in one or more of the following ways:
a. Cognitively (through discussion, planning, and education) ${ }^{224}$
b. Physically (action rituals, rest periods) ${ }^{225}$
c. Emotionally (through rituals, expression of feelings) ${ }^{226}$
d. Spiritually (through funeral ceremonies) ${ }^{227}$
e. Creatively (through the arts) (28 $^{22}$
f. Practically (through legal action, relocation, and physical resource development) ${ }^{229}$

\footnotetext{
${ }^{223}$ Archer, "The Nature of Grief," 111.

${ }^{224}$ Zinner et al., "The Connection Between Grief and Trauma," 15.

${ }^{225}$ Ibid.

${ }^{226}$ Ibid.

${ }^{227}$ Ibid.

${ }^{228}$ Ibid.

${ }^{229}$ Ibid.
} 
Table II: The Oklahoma Museum Association and A Day for Children

\begin{tabular}{|c|c|c|c|}
\hline $\begin{array}{l}\text { Components of healing, } \\
\text { resolution of grief, and/or } \\
\text { tools utilized by } \\
\text { community leaders }\end{array}$ & Implemented? & $\begin{array}{c}\text { If implemented, how } \\
\text { so? }\end{array}$ & Resources used \\
\hline $\begin{array}{l}\text { 1. Fostered personal } \\
\text { connections }\end{array}$ & $\mathrm{X}$ & $\begin{array}{l}\text { Event gathered } \\
\text { children in Oklahoma } \\
\text { City together. }\end{array}$ & Space \\
\hline 2. Rituals or ceremonies & $\mathrm{X}$ & $\begin{array}{l}\text { A tree planting } \\
\text { ceremony was } \\
\text { organized. }^{231}\end{array}$ & $\begin{array}{l}\text { Space, new } \\
\text { programming }\end{array}$ \\
\hline \multicolumn{4}{|l|}{ 3. Acts of creation } \\
\hline 4. Reprieve from tragedy & $X$ & $\begin{array}{l}\text { A Day for Children } \\
\text { was not intended to } \\
\text { deal directly with the } \\
\text { tragedy, but rather } \\
\text { provide a distraction } \\
\text { from the tragedy and } \\
\text { help children regain a } \\
\text { sense of normalcy. }\end{array}$ & $\begin{array}{l}\text { Space, new and } \\
\text { existing } \\
\text { programming, } \\
\text { partnerships }\end{array}$ \\
\hline 5. Social support & $\mathrm{X}$ & $\begin{array}{l}\text { Staff wanted to } \\
\text { reassure children that } \\
\text { museums are safe } \\
\text { spaces run by trusted } \\
\text { adults. }{ }^{233}\end{array}$ & $\begin{array}{l}\text { Space, } \\
\text { partnerships }\end{array}$ \\
\hline \multicolumn{4}{|l|}{ 6a. Cognitive response } \\
\hline 6b. Physical response & $\mathrm{X}$ & $\begin{array}{l}\text { Event provided a } \\
\text { distraction from the } \\
\text { realities of the } \\
\text { tragedy. }\end{array}$ & \\
\hline \multicolumn{4}{|l|}{ 6c. Emotional response } \\
\hline \multicolumn{4}{|l|}{ 6d. Spiritual response } \\
\hline 6e. Creative response & $\mathrm{X}$ & $\begin{array}{l}\text { Children could attend } \\
\text { performances by a } \\
\text { storyteller, clown, and } \\
\text { harpist. }\end{array}$ & $\begin{array}{l}\text { Space, new } \\
\text { programming }\end{array}$ \\
\hline 6f. Practical response & & & \\
\hline
\end{tabular}

${ }^{230}$ O'Donnell, "The Muse of Good Will in Oklahoma City," 9.

${ }^{231}$ Ibid., 11.

232 Ibid., 10.

${ }^{233}$ Ibid., 11-14.

${ }^{234}$ Ibid., 10.

${ }^{235}$ Ibid. 11. 
Table III: The Experience Music Project Museum and the Death of Michael Jackson

\begin{tabular}{|c|c|c|c|}
\hline $\begin{array}{l}\text { Components of healing, } \\
\text { resolution of grief, } \\
\text { and/or tools utilized by } \\
\text { community leaders }\end{array}$ & $\begin{array}{l}\text { Imple- } \\
\text { mented? }\end{array}$ & If implemented, how so? & $\begin{array}{l}\text { Resources } \\
\text { used }\end{array}$ \\
\hline $\begin{array}{l}\text { 1. Fostered personal } \\
\text { connections }\end{array}$ & $\mathrm{X}$ & $\begin{array}{l}\text { The museum provided a space } \\
\text { where mourners could be in the } \\
\text { presence of other fans. }\end{array}$ & Space \\
\hline 2. Rituals or ceremonies & $X$ & $\begin{array}{l}\text { EMP hosted a viewing of Michael } \\
\text { Jackson's memorial service in the } \\
\text { Sky Church. }\end{array}$ & $\begin{array}{l}\text { Space, new } \\
\text { programming }\end{array}$ \\
\hline 3. Acts of creation & $X$ & $\begin{array}{l}\text { Mourners could draw or write } \\
\text { outside the museum with } \\
\text { sidewalk chalk or inside the } \\
\text { museum with markers on butcher } \\
\text { paper. }\end{array}$ & $\begin{array}{l}\text { Space, new } \\
\text { programming }\end{array}$ \\
\hline \multicolumn{4}{|l|}{ 4. Reprieve from tragedy } \\
\hline 5. Social support & $X$ & $\begin{array}{l}\text { EMP created a community space } \\
\text { where mourners could come and } \\
\text { celebrate Jackson. }{ }^{239}\end{array}$ & $\begin{array}{l}\text { Space, new } \\
\text { programming }\end{array}$ \\
\hline \multicolumn{4}{|l|}{ 6a. Cognitive response } \\
\hline \multicolumn{4}{|l|}{ 6b. Physical response } \\
\hline 6c. Emotional response & $X$ & $\begin{array}{l}\text { Mourners could express their } \\
\text { feelings and emotions via the } \\
\text { visitor interactives of the sidewalk } \\
\text { chalk and/or markers; mourners } \\
\text { could make personal connections } \\
\text { to Jackson's belongings. }{ }^{240}\end{array}$ & $\begin{array}{l}\text { New } \\
\text { programming, } \\
\text { exhibit/ } \\
\text { display of } \\
\text { collection }\end{array}$ \\
\hline \multicolumn{4}{|l|}{ 6d. Spiritual response } \\
\hline 6e. Creative response & $X$ & $\begin{array}{l}\text { EMP used footage from Jackson's } \\
\text { performance at the } 25^{\text {th }} \\
\text { anniversary of Motown special on } \\
\text { view in the Sky Church. } \\
\text { Mourners could also express } \\
\text { themselves artistically via the } \\
\text { sidewalk chalk and/or markers. }\end{array}$ & $\begin{array}{l}\text { Space, new } \\
\text { programming }\end{array}$ \\
\hline 6f. Practical response & & & \\
\hline
\end{tabular}

\footnotetext{
236 "Fans Gather at EMP to Remember Jackson."

${ }^{237} \mathrm{Jacob} \ldots$ _ personal interview with author.

${ }^{238}$ Ibid.

${ }^{239}$ Ibid.

${ }^{240}$ Ibid.

${ }^{241}$ Ibid.
} 
Table IV: The Field Museum and September 11, 2001

\begin{tabular}{|c|c|c|c|}
\hline $\begin{array}{l}\text { Components of healing, } \\
\text { resolution of grief, } \\
\text { and/or tools utilized by } \\
\text { community leaders }\end{array}$ & $\begin{array}{l}\text { Imple- } \\
\text { mented? }\end{array}$ & If implemented, how so? & Resources used \\
\hline $\begin{array}{l}\text { 1. Fostered personal } \\
\text { connections }\end{array}$ & $\mathrm{X}$ & $\begin{array}{l}\text { The museum provided a space } \\
\text { where people could "be in the } \\
\text { presence of other human } \\
\text { beings." } 242\end{array}$ & Space \\
\hline \multicolumn{4}{|l|}{ 2. Rituals or ceremonies } \\
\hline \multicolumn{4}{|l|}{ 3. Acts of creation } \\
\hline 4. Reprieve from tragedy & $\mathrm{X}$ & $\begin{array}{l}\text { The museum served as a "place } \\
\text { for people looking to get away } \\
\text { from the television." } 243\end{array}$ & $\begin{array}{l}\text { Space, new and } \\
\text { existing } \\
\text { programming }\end{array}$ \\
\hline 5. Social support & $\mathrm{X}$ & $\begin{array}{l}\text { Field staff wanted to be a } \\
\text { community gathering place that } \\
\text { could be used by community } \\
\text { members in a variety of ways. }\end{array}$ & $\begin{array}{l}\text { Space, new and } \\
\text { existing } \\
\text { programming }\end{array}$ \\
\hline 6a. Cognitive response & $\mathrm{X}$ & $\begin{array}{l}\text { Panel discussions provided } \\
\text { context and a deeper } \\
\text { understanding of issues that arose } \\
\text { after the terrorist attacks }\end{array}$ & $\begin{array}{l}\text { Space, staff } \\
\text { expertise, } \\
\text { partnerships, } \\
\text { exhibit/display } \\
\text { of collection, } \\
\text { new and existing } \\
\text { programming }\end{array}$ \\
\hline 6b. Physical response & $\mathrm{X}$ & $\begin{array}{l}\text { The museum provided a place of } \\
\text { refuge following the attacks. }{ }^{246}\end{array}$ & Space \\
\hline 6c. Emotional response & $\mathrm{X}$ & $\begin{array}{l}\text { The town hall panel discussions } \\
\text { gave people the opportunity to } \\
\text { express their feelings and ask } \\
\text { questions. }\end{array}$ & $\begin{array}{l}\text { Space, } \\
\text { partnerships, } \\
\text { staff expertise, } \\
\text { new } \\
\text { programming }\end{array}$ \\
\hline \multicolumn{4}{|l|}{ 6d. Spiritual response } \\
\hline 6e. Creative response & $\mathrm{X}$ & $\begin{array}{l}\text { The Field hosted concerts by the } \\
\text { Chicago Children's Choir and the } \\
\text { theatrical performance, Surviving } \\
\text { Violence. }\end{array}$ & $\begin{array}{l}\text { Space, } \\
\text { partnerships, } \\
\text { new } \\
\text { programming }\end{array}$ \\
\hline 6f. Practical response & & & \\
\hline
\end{tabular}

\footnotetext{
${ }^{242}$ Lusaka, "Community Gathering," 62-63.

${ }^{243}$ Ibid.

244 Ibid.

${ }^{245}$ Ibid., 62.

${ }^{246}$ Ibid., 62-63.

${ }^{247}$ Ibid.

${ }^{248}$ Ibid., 65.
} 
Table V: The Oakland Museum of California and the Days of the Dead celebration in honor of Chauncey Bailey

\begin{tabular}{|c|c|c|c|}
\hline $\begin{array}{l}\text { Components of } \\
\text { healing, resolution of } \\
\text { grief, and/or tools } \\
\text { utilized by community } \\
\text { leaders }\end{array}$ & $\begin{array}{l}\text { Imple- } \\
\text { mented? }\end{array}$ & If implemented, how so? & $\begin{array}{l}\text { Resources } \\
\text { used }\end{array}$ \\
\hline $\begin{array}{l}\text { 1. Fostered personal } \\
\text { connections }\end{array}$ & $X$ & $\begin{array}{l}\text { The museum used an annual } \\
\text { community event to bring people } \\
\text { together to honor Chauncey Bailey. }\end{array}$ & $\begin{array}{l}\text { Space, annual } \\
\text { event/existing } \\
\text { programming }\end{array}$ \\
\hline 2. Rituals or ceremonies & $X$ & $\begin{array}{l}\text { Traditions from Dias de los Muertos } \\
\text { (Days of the Dead) were the basis for } \\
\text { the event, including the creation of } \\
\text { ofrendas or altars honoring the } \\
\text { deceased. }\end{array}$ & $\begin{array}{l}\text { Annual } \\
\text { event/existing } \\
\text { programming, } \\
\text { partnerships }\end{array}$ \\
\hline 3. Acts of creation & $X$ & $\begin{array}{l}\text { Artists, school groups, and } \\
\text { community members built } \\
\text { ofrendas. }\end{array}$ & $\begin{array}{l}\text { Partnerships, } \\
\text { annual } \\
\text { event/existing } \\
\text { programming }\end{array}$ \\
\hline \multicolumn{4}{|l|}{$\begin{array}{l}\text { 4. Reprieve from } \\
\text { tragedy }\end{array}$} \\
\hline 5. Social support & $X$ & $\begin{array}{l}\text { OMCA had the tools available to help } \\
\text { their community and utilized those } \\
\text { tools. }\end{array}$ & $\begin{array}{l}\text { Space, annual } \\
\text { event/existing } \\
\text { programming }\end{array}$ \\
\hline \multicolumn{4}{|l|}{ 6a. Cognitive response } \\
\hline \multicolumn{4}{|l|}{ 6b. Physical response } \\
\hline 6c. Emotional response & $X$ & $\begin{array}{l}\text { Visitors could express their emotions } \\
\text { and/or leave messages for Chauncey } \\
\text { Bailey or his family via a comment } \\
\text { book. }\end{array}$ & $\begin{array}{l}\text { Annual } \\
\text { event/existing } \\
\text { programming }\end{array}$ \\
\hline 6d. Spiritual response & $X$ & $\begin{array}{l}\text { The formation of ofrendas has roots } \\
\text { in Mesoamerican culture and } \\
\text { Catholicism. }\end{array}$ & $\begin{array}{l}\text { Annual } \\
\text { event/existing } \\
\text { programming }\end{array}$ \\
\hline 6e. Creative response & $X$ & $\begin{array}{l}\text { Artists, school groups, and } \\
\text { community members built } \\
\text { ofrendas. }\end{array}$ & $\begin{array}{l}\text { Partnerships, } \\
\text { annual } \\
\text { event/existing } \\
\text { programming }\end{array}$ \\
\hline 6f. Practical response & & & \\
\hline
\end{tabular}

249 "The Morning Show - October 11, 2007 at 7:00am."

${ }^{250}$ Ibid.

${ }^{251}$ Simon, The Participatory Museum, Chapter 8.

252 "The Morning Show - October 11, 2007 at 7:00am."

${ }^{253}$ Evelyn ___ phone interview with author, 5 April 2012.

254 "The Morning Show - October 11, 2007 at 7:00am."

${ }^{255}$ Simon, The Participatory Museum, Chapter 8. 
Table VI: Case study comparisons: resources used

\begin{tabular}{|c|c|c|c|c|c|}
\hline Resources used & OMA & EMP & Field & OMCA & Totals \\
\hline Space & $\mathrm{X}$ & $\mathrm{X}$ & $\mathrm{X}$ & $\mathrm{X}$ & $100 \%$ \\
\hline Partnerships & $\mathrm{X}$ & & $\mathrm{X}$ & $\mathrm{X}$ & $75 \%$ \\
\hline New programming & $\mathrm{X}$ & $\mathrm{X}$ & $\mathrm{X}$ & $\mathrm{X}$ & $100 \%$ \\
\hline $\begin{array}{c}\text { Use of existing } \\
\text { programming }\end{array}$ & $\mathrm{X}$ & & $\mathrm{X}$ & $\mathrm{X}$ & $75 \%$ \\
\hline $\begin{array}{c}\text { Staff expertise } \\
\text { collection }\end{array}$ & & $\mathrm{X}$ & $\mathrm{X}$ & & $50 \%$ \\
\hline
\end{tabular}

All case study museums utilized a variety of existing resources. Of the case studies, $100 \%$ of the museums used the space and facilities of the institution. The Oklahoma Museums Association "A Day for Children" event used spaces at participating museums for children's activities. The Experience Music Project Museum had an accessible space that suited the activities of hosting viewings of the $25^{\text {th }}$ anniversary of Motown and Michael Jackson's memorial. The Field Museum had the facilities and space available for hosting the panel discussions, theatrical performance, and choir concerts. The Oakland Museum of California utilized the galleries and museum gardens to host the exhibit and community celebration to honor Chauncey Bailey.

In three out of four (75\%) case studies, collaboration and partnership with other organizations or individuals contributed to the implementation of these programs. OMA collaborated with partners throughout the Association and museums in residence at the Kirkpatrick Center. The Field called on community contacts to serve on the panels and to implement the theatrical production and choir concerts. In Oakland, the annual Days of the Dead celebration was conceptualized and implemented in collaboration with existing partnerships with artists, schools, and community groups. 
At OMCA and the Field, staff expertise was used. At OMCA, staff documented the changes to the spontaneous memorial for Chauncey Bailey and later incorporated those photos into the Ancient Roots/Urban Journeys: Expressions for Dias de los Muertos exhibit. At the Field, staff members whose expertise was in areas relating to the town hall discussions served as panelists.

OMA, EMP, and the Field created new programs or events following the bombing of the Murrah Federal Building, Jackson's death, and the terrorist attacks of 9/11, respectively. In Oakland, new programming and exhibits were incorporated into the Days of the Dead celebration in order to provide a tribute to Chauncey Bailey. Existing programming was also utilized at OMA, OMCA, and the Field. The Oklahoma Museums Association used the already available F-16 flight simulator at the Air and Space Museum as an activity for children. The Oakland Museum of California used the long established annual Days of the Dead celebration to address the murder of Bailey, and the Field used an already existing exhibit as a springboard for interpreting the events of $9 / 11$.

Making use of exhibits and displaying the museum's collection was done at EMP, which had Michael Jackson's glove and jacket, as well as at the Field, where the exhibit on cultural diversity, Living Together, took on new meaning following 9/11.

All actions performed by these museum case study examples were in response to issues that had an effect on community which the museum serves. Museums at Oklahoma City's Kirkpatrick Center reached out to the community of Oklahoma City school children. EMP reached out to the community of music fans to provide ways to honor Michael Jackson. The Field served the community of Chicago looking to understand or find a reprieve from the events 
of 9/11. The Oakland Museum of California provided a tribute where Oakland community members could honor Chauncey Bailey, a person of particular prominence in that city.

Lastly, at all events and programs, the museums made these activities free to the public, either by finding underwriting sponsors (The Field), operating in an area which is already free to the public (EMP), or by making the event especially free of charge (OMA, OMCA).

Table VII: Case study comparisons: components of healing

\begin{tabular}{|l|c|c|c|c|c|}
\hline $\begin{array}{l}\text { Components of } \\
\text { healing, resolution of } \\
\text { grief, and/or tools } \\
\text { utilized by community } \\
\text { leaders }\end{array}$ & OMA & EMP & Field & OMCA & Totals \\
\hline $\begin{array}{l}\text { 1. Fostered personal } \\
\text { connections }\end{array}$ & $\mathrm{X}$ & $\mathrm{X}$ & $\mathrm{X}$ & $\mathrm{X}$ & $100 \%$ \\
\hline $\begin{array}{l}\text { 2. Rituals or } \\
\text { ceremonies }\end{array}$ & $\mathrm{X}$ & $\mathrm{X}$ & $\mathrm{X}$ & $\mathrm{X}$ & $75 \%$ \\
\hline 3. Acts of creation & & $\mathrm{X}$ & $\mathrm{X}$ & $\mathrm{X}$ & $50 \%$ \\
\hline $\begin{array}{l}\text { 4. Reprieve from } \\
\text { tragedy }\end{array}$ & $\mathrm{X}$ & $\mathrm{X}$ & $\mathrm{X}$ & $\mathrm{X}$ & $100 \%$ \\
\hline 5. Social support & & $\mathrm{X}$ & & $25 \%$ \\
\hline 6a. Cognitive response & & $\mathrm{X}$ & $\mathrm{X}$ & $\mathrm{X}$ & $75 \%$ \\
\hline 6b. Physical response & & $\mathrm{X}$ & $\mathrm{X}$ & $\mathrm{X}$ & $100 \%$ \\
\hline 6c. Emotional response & & & & & $0 \%$ \\
\hline 6d. Spiritual response & & $\mathrm{X}$ & & $25 \%$ \\
\hline 6e. Creative response & & & & \\
\hline 6f. Practical response & & & & & \\
\hline
\end{tabular}

Of the 11 recognized healing components, OMA utilized 5/11 (45\%), EMP utilized 6/11 (54\%), and the Field and OMCA both utilized 7/11 (63\%). These healing components were facilitated through response actions of the staff by using a variety of resources available to the museum.

From the findings, it is evident that $100 \%$ of the case study museums fostered personal connections and provided social support by making their spaces open and available to the public. All museums also utilized a creative response through the arts. Two-thirds, or $75 \%$, of the case 
study museums offered rituals or ceremonies and a forum for the expression of emotion. Half of the museums gave visitors opportunities for acts of creation as well as a reprieve from the tragedy. Only one museum (25\%) each provided a cognitive response, physical response, and spiritual response. No museum responded practically through legal action, relocation, or physical resource development. These facts are indicative of the resources available to the individual museum and the capacity of staff to respond:

1. All museums had a space that could be shared and opened to the public

2. All museums had the capacity to facilitate a creative response through the arts

3. OMA, EMP, and OMCA had programming that provided a ritual or ceremony

4. EMP, the Field, and OMCA provided programming or visitor interactives that encouraged the expression of emotion

5. OMA and the Field provided programming and space that offered a reprieve by offering activities that did not deal directly with the tragedy

6. Only the Field offered a cognitive response (discussion, planning, education) via the town hall style speaker panels

7. Only the Field provided a space of refuge from $9 / 11$ and the imagery of the tragedy, though this could be indicative of the uniqueness of $9 / 11$ and the constant press coverage not seen in the other case study tragedies

8. Only OMCA offered programming that in part dealt with a spiritual response through the traditions of Dia de los Muertos

9. No museum provided a practical response, as these resources are not typically accessible or in the scope of museum practice 


\section{Chapter V: Conclusions and Recommendations}

A number of conclusions can be drawn from this study. Museums can be effective places for the resolution of grief and transcendence of suffering because they provide spaces for social support and personal connections. Museums can also utilize their unique individual resources through a variety of community responses which help contribute to the resolution of grief.

Museum spaces provide areas for people to come together and be a forum for personal connections that are vital to the healing process. Museums can use their unique individual resources, such as space, exhibits or display of the collection, staff expertise, partnerships, and new or existing programming. These resources can be used to respond to communities facing tragedy in a variety of ways, including cognitively, through discussion, planning, and education; physically, by providing spaces for rest and refuge; emotionally, through the expression of feelings; spiritually, through funeral ceremonies; and creatively, through the arts and/or acts of creation. $^{256}$

Based on the findings, to produce a positive impact amongst audiences, a museum must provide an accessible space to the public as a means of social support and forum for fostering personal connections. It also appears that utilizing internal resources, especially already existing partnerships, may be critical in the implementation of a museum institutional response to tragedy.

\section{Recommendations}

In order for a museum to respond quickly to tragedy, it is recommended that a museum have an internal culture that supports these initiatives. This could involve the

\footnotetext{
${ }^{256}$ Zinner et al., "The Connection Between Grief and Trauma," 15.
} 
development of policies that support rapid responses as integrated in a museum's disaster planning processes and inclusion in museum mission statements.

It is also recommended that museums cultivate and maintain ongoing collaborative partnerships with individuals and organizations, as these partnerships may lead to a more effective response by a museum following tragedy.

Museums could be places for spontaneous memorials, as memorials can promote healing and may be used as springboards for programming which can engage communities.

\section{Key Limitations}

Key limitations and opportunities for future research emerged from this study. Firstly, the sample size is small and consisted only of larger museums in urban areas. Secondly, with the exception of the Day of the Dead celebration at the Oakland Museum of California, no formal evaluations occurred for the case study programs or exhibits, therefore feedback from participants was purely observed or anecdotal. The evaluations at OMCA that were completed were not available for analysis for this research. Lastly, finding individuals to interview in the cases of the Field Museum and the Oklahoma Museums Association was particularly difficult, being that both events occurred over ten years ago and locating staff who were involved with the museum at that time was unfruitful. 


\section{Bibliography}

"9/11 Attacks." History.com. http://www.history.com/topics/9-11-attacks (accessed 1 April 2012).

"About the Museum of Broken Relationships." The Museum of Broken Relationships. http://brokenships.com/en/about (accessed 20 February 2012).

"About the Oakland Museum of California." The Oakland Museum of California. http://museumca.org/about (accessed 2 April 2012).

Abram, Ruth. "When the Sky Falls: The Lower East Side Tenement Museum Responds to September 11 ${ }^{\text {th } . " ~ H i s t o r y ~ N e w s, ~ 57, ~ n o . ~} 1$ (Winter 2002): 6-11.

Alexander, Edward P. and Mary Alexander. Museums in Motion: An Introduction to the History and Functions of Museums. New York: AltaMira Press, 2008.

“Ancient Roots/Urban Journeys: Expressions for Dias de los Muertos." The Oakland Museum of California. http://museumca.org/exhibit/exhi_days_of_dead.html (accessed 9 April 2012).

Archer, John. The Nature of Grief: The Evolution and Psychology of Reactions to Loss. New York: Routledge, 1999.

Atkinson, Nora. "From the Curator." In Making Mends exhibition catalogue, Bellevue, WA: Bellevue Arts Museum, 2012.

Beaton, Randal. "Psychosocial Responses to Biological and Chemical Terrorist Threats and Events: Implications for the Workplace - The aftermath of previous traumatic events can enlighten nurses about what to expect." AAOHN Journal : Official Journal of the American Association of Occupational Health Nurses, no. 4 (2002): 182-189.

Binnie, Jennifer. "Does Viewing Art in the Museum Reduce Anxiety and Improve Wellbeing?" Museums \& Social Issues, no. 2 (2010): 191-201.

Bolton, David. "The Threat to Belonging in Enniskillen: Reflections of the Remembrance Day Bombing." In When a Community Weeps: Case Studies in Group Survivorship, edited by Ellen S. Zinner and Mary Beth Williams, 191-211. Philadelphia: Brunner/Mazel, 1999.

Briere, John and Catherine Scott. Principles of Trauma Therapy: A Guide to Symptoms, Evaluation, and Treatment. Thousand Oaks, CA: Sage Publications, Inc., 2006.

"Chauncey Bailey." The Chauncey Bailey Project. http://www.chaunceybaileyproject.org/about/chauncey-bailey/ (accessed 2 April 2012). 
Christiansen, Jim. "Rituals and Their Importance." In The Memorial Rituals Book for Healing and Hope, edited by Ann Marie Putter, 5. Amityville, NY: Baywood Publishing Company, Inc., 1997.

Collins, Jim. Good to Great and the Social Sectors. New York: Harper Collins, 2005.

"Comments By Chaim Potok." Facing History and Ourselves. http://www2.facinghistory.org/Campus/memorials.nsf/PrintView/DE9B4E8C4798B9538 5256ECF0070413E?OpenDocument (accessed 16 February 2012).

Egnew, Thomas R. "The Meaning of Healing: Transcending Suffering.” Annals of Family Medicine, no. 3 (May/June 2005): 255-262.

"Fans Gather at EMP to Remember Jackson." KIRO TV Seattle. http://www.kirotv.com/news/news/fans-gather-at-emp-to-remember-jackson/nKXJK/ (accessed 30 March 2012).

"FAQ About 9/11." National September 11 Memorial and Museum. http://www.911memorial.org/faq-about-911 (accessed 11 May 2012).

Gardner, James B., and Sarah M. Henry. "September 11 and the Mourning After: Reflections on Collecting and Interpreting the History of Tragedy." The Public Historian 24, no. 3 (Summer 2002): 37-52.

Gross, Dick. "Steve Jobs and the Marking of Death." The Sydney Morning Herald, 24 October 2011.

Gurian, Elaine Heumann. "A Savings Bank for the Soul.” In Civilizing the Museum: The Collected Writings of Elaine Heumann Gurian, edited by Elaine Huemann Gurian, 88-96. New York: Routledge, 2006.

Gurian, Elaine Heumann. "Timeliness." In Civilizing the Museum: The Collected Writings of Elaine Heumann Gurian, edited by Elaine Huemann Gurian, 57-66. New York: Routledge, 2006.

"How the Concerts Started." The National Gallery. http://www.nationalgallery.org.uk/paintings/history/myra-hess-concerts/how-theconcerts-started (accessed 9 February 2012).

Johnson, Kendall. After the Storm: Healing After Trauma, Tragedy and Terror. Berkeley: Hunter House, 2006.

Kimmelman, Michael. "The Solace in Sharing the Beauty of Great Art and Music.” New York Times, 17 September 2001. 
Kroslowitz Karen. "Spontaneous Memorials: Forums for Dialog and Discourse." Museums and Social Issues, no. 2 (2007): 243-255.

Lusaka, Jane. "Community Gathering: A Report from the Field." Museum News 80, no. 6 (November/December 2001): 37-65.

"Michael Jackson." Biography. http://www.biography.com/people/michael-jackson38211?page $=1$ (accessed 30 March 2012).

"Mourning Diana." Historic Royal Palaces: Kensington Palace. http://www.hrp.org.uk/KensingtonPalace/stories/dianasdeath (accessed 29 March 2012).

"Museum Definition." International Council of Museums. http://icom.museum/who-we-are/thevision/museum-definition.html (accessed 9 February 2012).

"Museum Relevance: What I Learned from Michael Jackson." Museum 2.0. http://museumtwo.blogspot.com/search?q=jackson, (accessed 13 April 2012).

“Myra Hess' Wartime Concerts.” The National Gallery. http://www.nationalgallery.org.uk/paintings/history/myra-hess-concerts/the-myra-hessconcerts (accessed 9 February 2012).

Nurmi, Lasse A. and Mary Beth Williams. "Death of a Co-Worker: Conceptual Overview." In Death and Trauma: the Traumatology of Grieving, edited by Figley et al., 43-61. Washington: Taylor and Francis, 1997.

O’Donnell, Susannah Cassedy. "The Muse of Good Will in Oklahoma City," Museum News, no. 74 (July/August 1995): 9-14.

"Oklahoma City Attractions." Planet Ware. http://www.planetware.com/tourist-attractions/oklahoma-city-us-ok-okc.htm (accessed 1 April 2012).

“Oklahoma City Bombing vs. Sept. 11.” CBS News. http://www.cbsnews.com/2100500164_162-550231.html (accessed 1 April 2012).

Oldenburg, Ray. The Great Good Place: Cafes, coffee shops, community centers, beauty parlors, general stores, bars, hangouts and how they get you through the day. New York: Paragon House, 1989.

"Private Events at EMP SFM.” Experience Music Project Museum. http://www.empmuseum.org/documents/privateEvents/PrivateEventsAtEMPSFM.pdf, (accessed 30 March 2012).

"School-Aged Children and Grief." The Healing Center. http://www.healingcenterseattle.org/children/childrens-grief/ (accessed 6 May 2012). 
Schwarzer, Marjorie. Riches, Rivals \& Radicals: 100 Years of Museums in America. Washington: American Association of Museums, 2006.

Silverman, Lois H. The Social Work of Museums. New York: Routledge, 2010.

Simon, Nina. The Participatory Museum. Santa Cruz: Museum 2.0, 2010. Online book: http://www.participatorymuseum.org/read/.

Sitterle, Karen A. and Robin H. Gurwitch. "The Terrorist Bombing in Oklahoma City." In When a Community Weeps: Case Studies in Group Survivorship, edited by Ellen S. Zinner and Mary Beth Williams, 161-188. Philadelphia: Brunner/Mazel, 1999.

Tatelbaum, Judy. The Courage to Grieve. New York: Harper and Row Publishers, 1980.

"Terror Hits Home: The Oklahoma City Bombing." Federal Bureau of Investigation. http://www.fbi.gov/about-us/history/famous-cases/oklahoma-city-bombing (accessed 1 April 2012).

“The Morning Show - October 11, 2007 at 7:00am." KPFA Radio Berkeley. http://www.kpfa.org/archive/id/7291 (accessed 16 March 2012).

“The Murder of Chauncey Bailey.” CBS News. http://www.cbsnews.com/2100-18560_1623861939.html (accessed 16 March 2012).

“Those Who Were Killed: Miss Baylee Almon." Oklahoma City National Memorial and Museum. http://www.oklahomacitynationalmemorial.org/secondary.php?section=1\&ordering=5\&c atid=24 (accessed 26 March 2012).

“Today in Black History, 11/29/2011." Charles H. Wright Museum of African American History. http://www.thewright.org/component/content/article/1/560 (accessed 29 February 2012).

"Vision and Mission." Experience Music Project Museum. http://www.empmuseum.org/aboutEMP/index.asp?categoryID=285, (accessed 30 March 2012).

Zinner, Ellen S., et al. "The Connection Between Grief and Trauma." In When a Community Weeps: Case Studies in Group Survivorship, edited by Ellen S. Zinner and Mary Beth Williams, 3-17. Philadelphia: Brunner/Mazel, 1999.

, Evelyn. Project Director, Oakland Museum of California, Oakland, CA. Phone interview with author, 5 April 2012.

, Jacob. Curator, Experience Music Project Museum, Seattle, WA. Personal interview with author, Seattle, WA, 8 March 2012. 


\section{Appendices}

\section{UNIVERSITY OF WASHINGTON \\ CONSENT FORM \\ Thesis Research - Museum Institutional Responses to Tragedy \\ Oakland Museum of California}

Researcher: Anne Melton, 206- _-_ amelton@uw.edu

\section{Researcher's statement}

You are being asked to participate in a research study. The purpose of this consent form is to give you the information you will need to help you decide whether to be in the study or not. Please read the form carefully. You may ask questions about the purpose of the research, what we would ask you to do, the possible risks and benefits, your rights as a volunteer, and anything else about the research or this form that is not clear. When we have answered all your questions, you can decide if you want to be in the study or not. This process is called "informed consent." We will give you a copy of this form for your records.

\section{PURPOSE OF THE STUDY}

This interview is intended to gather research for my thesis paper as part of my graduate study in the Museology Graduate Program at the University of Washington. My research consists of identifying case studies in which museums have responded in the aftermath of tragic events in order to be of service to their communities, and the possibility of these actions contributing to the healing or resolution of grief of their audiences. You have been identified because of your connection to the case study involving the Oakland Museum of California's Days of the Dead celebration honoring slain journalist Chauncey Bailey in October of 2007.

\section{STUDY PROCEDURES}

The study will consist of a 30-60 minute interview of the following questions:

1. At the time of the 2007 Day of the Dead celebration honoring Chauncey Bailey, what was your title at the museum?

2. In the aftermath of Bailey's death, how did OMCA respond?

3. What were the processes put into place by the museum to develop this public program? What drove you and other staff to take action?

4. Why did you and/or people at your institution feel it was necessary to hold a tribute to Mr. Bailey?

5. What were the goals of these programs?

6. Did you ever consider or hope that your actions would help to promote healing in your community? Why?

7. Did you feel these actions were representative of your responsibilities as a museum professional or your institution's position in the community?

8. Do you think these programs were successful? Why so? Was an evaluation done?

9. Is there anything else you would like to add? 


\section{RISKS, STRESS, OR DISCOMFORT}

Professionals may miss 30-60 minutes of work, and discomfort is possible when recounting memories of traumatic events.

\section{BENEFITS OF THE STUDY}

This research will identify ways in which museums have responded to tragic events in order to be of service to their communities. By providing specific examples of potential ways and the broad spectrum to be of service, ideally, museum professionals can gain an understanding of how best to serve and respond to their communities in the aftermath of tragedy.

\section{Who will have access}

Only I, Anne Melton, will have access to the original notes taken during the interview. My thesis committee will only see a summary or analysis of the data.

\section{CONFIDENTIALITY OF RESEARCH INFORMATION}

The data gathered from interviews will be used in my graduate thesis paper. Individuals will be identified by first name, professional area of expertise, and institution unless otherwise requested by the interviewee.

\section{OTHER INFORMATION}

You may refuse to participate and you are free to decline to answer specific questions or end the interview at any time.

Printed name of researcher obtaining consent

Signature

Date

Subject's statement

This study has been explained to me. I volunteer to take part in this research. I have had a chance to ask questions. If I have questions later about the research, I can ask one of the researchers listed above. If I have questions about my rights as a research subject, I can call the Human Subjects Division at (206) 543-0098. I give permission to Anne Melton to use my comments in her thesis research paper, and linked to me by my first name, title, and name of institution. I will receive a copy of this consent form. 


\section{UNIVERSITY OF WASHINGTON \\ CONSENT FORM \\ Thesis Research - Museum Institutional Responses to Tragedy \\ Experience Music Project Museum}

Researcher: Anne Melton, 206- $\square-\square$, amelton@uw.edu

\section{$\underline{\text { Researcher's statement }}$}

You are being asked to participate in a research study. The purpose of this consent form is to give you the information you will need to help you decide whether to be in the study or not. Please read the form carefully. You may ask questions about the purpose of the research, what we would ask you to do, the possible risks and benefits, your rights as a volunteer, and anything else about the research or this form that is not clear. When we have answered all your questions, you can decide if you want to be in the study or not. This process is called "informed consent." We will give you a copy of this form for your records.

\section{PURPOSE OF THE STUDY}

This interview is intended to gather research for my thesis paper as part of my graduate study in the Museology Graduate Program at the University of Washington. My research consists of identifying case studies in which museums have responded in the aftermath of tragic events in order to be of service to their communities, and the possibility of these actions contributing to the healing or resolution of grief of their audiences. You have been identified because of your connection to the case study involving the spontaneous memorial and memorial services at the Experience Music Project in June and July of 2009 following the death of musician Michael Jackson.

\section{STUDY PROCEDURES}

The study will consist of a 30-60 minute interview of the following questions:

1. At the time of the death of Michael Jackson, what was your title at the museum?

2. In the aftermath of Jackson's death, EMP responded by hosting a spontaneous memorial, holding a tribute, and hosting a viewing of Jackson's funeral. What were the processes put into place by the museum to develop these public programs? What drove you and other staff to take action?

3. What motivated you to respond so quickly?

4. Why did you and/or people at your institution feel it was necessary to host the spontaneous memorial, tribute, and funeral?

5. What were the goals of these programs?

6. Did you ever consider or hope that your actions would help to promote healing in your community? Why?

7. Did you feel these actions were representative of your responsibilities as a museum professional or your institution's position in the community?

8. Do you think these programs were successful? Why so? Was an evaluation done?

9. Is there anything else you would like to add? 
Interviews will be audio recorded at the consent of the interviewee and will be used as reference by the researcher while compiling data and/or results. Interviews will be stored on a password protected device, and deleted upon completion of research.

\section{RISKS, STRESS, OR DISCOMFORT}

Professionals may miss 30-60 minutes of work, and discomfort is possible when recounting memories of traumatic events.

\section{BENEFITS OF THE STUDY}

This research will identify ways in which museums have responded to tragic events in order to be of service to their communities. By providing specific examples of potential ways and the broad spectrum to be of service, ideally, museum professionals can gain an understanding of how best to serve and respond to their communities in the aftermath of tragedy.

\section{Who will have access}

The recordings will be kept on a password protected device and my Committee Chair and I will be the only ones to see/hear the original data. The committee will only see a summary or analysis of the data. Upon conclusion of my thesis paper, the recordings will be destroyed.

\section{CONFIDENTIALITY OF RESEARCH INFORMATION}

The data gathered from interviews will be used in my graduate thesis paper. Individuals will be identified by first name, professional area of expertise, and institution unless otherwise requested by the interviewee.

\section{OTHER INFORMATION}

You may refuse to participate and you are free to decline to answer specific questions or end the interview at any time.

Printed name of researcher obtaining consent

Signature

Date

\section{$\underline{\text { Subject's statement }}$}

This study has been explained to me. I volunteer to take part in this research. I have had a chance to ask questions. If I have questions later about the research, I can ask one of the researchers listed above. If I have questions about my rights as a research subject, I can call the Human Subjects Division at (206) 543-0098. I give permission to Anne Melton to use my comments in her thesis research paper, and linked to me by my first name, title, and name of institution. I will receive a copy of this consent form. 